\title{
Verdediging van belangen: het belang van de verdediging : enkele principiele en praktische vragen over de rol van de verdediging in strafzaken
}

Citation for published version (APA):

de Roos, T. A. (1991). Verdediging van belangen: het belang van de verdediging : enkele principiele en praktische vragen over de rol van de verdediging in strafzaken. Gouda Quint. https://doi.org/10.26481/spe.19911122tr

Document status and date:

Published: 22/11/1991

DOI:

10.26481/spe.19911122tr

Document Version:

Publisher's PDF, also known as Version of record

Please check the document version of this publication:

- A submitted manuscript is the version of the article upon submission and before peer-review. There can be important differences between the submitted version and the official published version of record.

People interested in the research are advised to contact the author for the final version of the publication, or visit the DOI to the publisher's website.

- The final author version and the galley proof are versions of the publication after peer review.

- The final published version features the final layout of the paper including the volume, issue and page numbers.

Link to publication

\footnotetext{
General rights rights.

- You may freely distribute the URL identifying the publication in the public portal. please follow below link for the End User Agreement:

www.umlib.nl/taverne-license

Take down policy

If you believe that this document breaches copyright please contact us at:

repository@maastrichtuniversity.nl

providing details and we will investigate your claim.
}

Copyright and moral rights for the publications made accessible in the public portal are retained by the authors and/or other copyright owners and it is a condition of accessing publications that users recognise and abide by the legal requirements associated with these

- Users may download and print one copy of any publication from the public portal for the purpose of private study or research.

- You may not further distribute the material or use it for any profit-making activity or commercial gain

If the publication is distributed under the terms of Article $25 \mathrm{fa}$ of the Dutch Copyright Act, indicated by the "Taverne" license above, 
Verdedliging van belangen:

het belang van de verdediging 
Tor mogednchens wan min pader 


\section{Verdediging van belangen: het belang van de verdediging}

Enkele principiele en praktische wragen over de rol van de verdediging in strafzaken

Rede

aitgesproken ter gelegenheid van de aanvaarding van het ambt van gewoon hoogleraar in het strafrecht en strafprocesrecht aan de Rijksuniversiteit Limburg te Maastricht: op vrijdag 22 november $199 \mathrm{I}$

door

Profmr. Th.A. de Roos

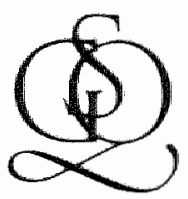

Gouda Quint BV

(S. Gouda Quint - D. Brouwer \& Zoon)

Arnhem 
1Hustratie op blz, 25: Karin wan Elderen

\section{CIP-CEGEVENS KONINKLIJKE BULLIOTHEEK, DEN HAAG}

Roos, Th.A. de

Verdedighing van belangen het belang van de verdediging: enkele principiele en praktische viagen ovar de rol wan de verdediging in strafzaken / Th.A. de Roos.

- Arnhem: Couda Quire

Inaugurele Rede Maaxtricht.

ISBN $90-6000-882-0$

NUGI 694

Trefw : strafprocestecht.

(C) Is)! Th. A de Roos

Alle redten woobehouden. Niets uit deze thitgape mag worden verwectvondigd, opgeslagen in

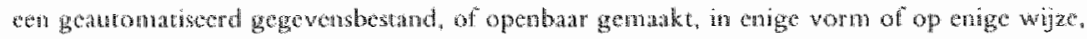
hezij dektronisch. mechanich, door fotocopien. opnamen, of enige andere manier, zonder vooafgands schtritwijke toestenming van de uitgever.

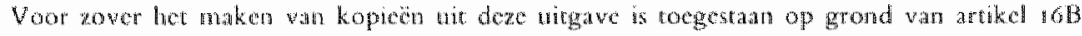

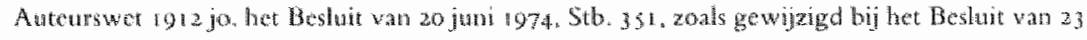

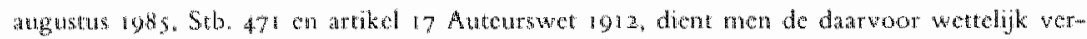

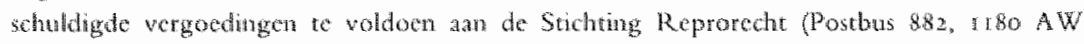
Anstelvecn). Voor het overnemen van gededte(n) wit dese untgave in blowmlezingen, readers en andre compilatewerken (artikel 16 Auterswet $19 \mathrm{~g}$ ) dient men zich tot de uitgever to wenden. 


\section{Dames en Heren}

\section{Inleiding}

Voordat het echtpaar Ceausescu eind 1989 werd geexxecuteerd, werd het berecht door een ad hoc tribunaal. Het ging hier om een schijnproces, waarin voor een werkelijke verdediging geen ruimte werd gelaten.

Opmerkelijk genoeg figureerde in dit proces ook een advocat. Uit de gang van zaken tijdens het macabere ritueel blijkt niet dat deze advocaat het vertrouwen van zijn 'cliènten' genoot, noch dat de verdediging met hen gezamenlijk was voorbereid. De bijdrage van de advocaat beperkte zich ertoe te verklaren, dat het dictatoriale span wat hun gezondheidstoestand betreft in stat was het proces mee te maken (wat ook naar onze normen inderdaad het geval leek), en dat de bewoegdheid van het tribunaal niet in twijfel. werd getrokken. Daarmee schaarde hij zich onomwonden an de zijde van degenen, die het proces hadden aangespannen, on liet hij zijn 'cliënten', die immers herhaaldelijk verklaarden het tribunaal niet te erkennen, witdrukkelijk vallen. Voor een advocaat is dat een doodzonde. Het is al bedenkelijk een opgelegd verweer te laten liggen; het is onvergeeflijk je cliënten uitdrukkelijk af te vallen, mar wanneer je bovendien nog eens de zijde van de vervolgende machthebbers kiest heb je jezelf als raadsman volstrekt gediskwalificeerd.

Dit is een extreem voorbeeld; het ging om een revolutionaire situatie. Het is merk waardig on te zien dat een opkomend regime, in cen nog uiterst onzekere situatie, voor de wereldopinie streeft naar legitimiteit, en daarbij het beproefde middel van het proces bezigt. Een proces met alle toeters en bellen, dus ook met een advocaat. Het is vooral de rol dic

"Zie Constantijn Kolk, Het tribunaal, in: Afgeschreven. Lhomme perdu. Zes beschouwingen rondom het thema "misdad en strat(reche), verlucht met zes achildorijen van Constant. Arnhem (Gouda Quint) 1990, blz. 73-83, n.n. bl\%. 79-80. 
deze advocaat speelt, die het beoogde doel van de vertoning - legitimiteitsverwerving - danig frustreert. Juist omdat deze advocaat kennelijk niet de belangen van zijn clienten dient, is hij ook onbruikbaar voor het doel voor de machthebbers. Men kan uit dit voorbeeld dus leren, dat er een bepaalde positieve relatie bestaat tussen de verdediging van de belangen van strafrechtelijk vervolgden in een tegen hen aangespannen procedure, en de bevordering van her belang van de gevestigde macht die uit is op instemming en ondersteuning door de (nationale en internationale) gemeenschap.

Een volkomen ander proces, duizenden jaren terug in de tijd: het proces tegen Socrates, in het Athene van de wierde eeuw voor Christus. Dit verloopt volkomen volgens de nationale regels van die tijd. Socrates, beschuldigd van 'asebeia' en het bederven wan de Atheense jeugd, krijgt alle kans om de dans te ontspringen, maar benut deze welbewust niet. Het proces voor de volkstechtbank bestat uit twee fasen: de vaststelling van de feiten, en het oordeel over de sanctie. In beide fasen lat Socrates alle kansen schieten om effectief verweer te voeren, met het gevolg dat het doodvonnis wordt uitgesproken. Zelfs de zeer reële mogelijkheid om zich aan de executie te ontrekken lat hij schieten. Op grond van zijn levensbeschouwing ziet hij deze dood als een begerenswaardig doel. Zijn proceshouding is voortdurend door dit doel bepaald. Waar hij de stellingen van zijn aanklager Anytos betwist is dat niet om dit gewilde resultaat af te wenden, maar om de integriteit van zijn levensbeschouwing tegenover het hof en het publick overeind te houden.

Socrates had geen advocaat. Toch was het ook in zijn tijd gebruikelijk zich als aangeklaagde partij te doen bijstaan. Er was - niet zonder weerstand overigens - een professionele kaste van thetoren, advocaten ann het ontstaan. ${ }^{3}$ Mar ongetwiffeld zou het optreden van een kundig

Vgl. I.F. Stone, Het proces Socrates. Boston, Toronto (Little, Brown and Company) 1988. Nederlandse wertaling door Jabik Veenbas: Barn (Sesam/Bosch \& Keuning). 1988/1989. Volgens Stone had Socrates gemakkelijk vrijspraak knnen krijgen, en decd hij zin best de jury tegen zich in het harmas te jagen. Deze wat ecnzijdige opvatting wordt door de atuteur meeslepend bepleit. Zie ook Gerard Koolsching, Plato selvrijwer. Ansterdam (Bert Bakker), 1987, m.n. blz. I I (ironische verdediging met de beroemde 'horzel'-wergeliking) en blz. 125 , met de uit de Crito vertalde passage wannin Socrates ajn "proceshouding" na de veroordeling verwoordt.

$6 \mathrm{Vgl}$. Jonny Scholten, Retoren en demokratie. Funkties en disfunkties van de retorika 
en alert raadsman alleen maar afbreuk hebben kumen doen am de doelbewuste strategie van deze vermaarde client. Samen met het eerstgenoemde proces, dat van de Ceausescu's, geeft de zaak-Socrates de indruk dat bijstand van een deskundige raadsman in cen proces vooral dan wan waarde is, wanneer het perspectief van de machthebbers word betwist, hun legitimiteit wordt angevochten (integraal of op onderdelen), dan wel de beschuldiging en de strafeis worden betwist of aangevochten en wanneer de bijstand noodzakelijk is om de zelfgekozen opstelling van de aangeklaagde goed uit de verf te laten komen.

Voor een beschouwing over de rechtsbijstand in strafzaken vormen deze voorbeelden schijnbaar een valse start, omdat zij beide negatief van aard zijn: geen van de genoemde 'verdachten' hadden bat bij rechtsbijstand. Het echtpaar Ceausescu niet, omdat hun raadsman die naam niet waardig was, Socrates niet, ondat hij zichzelf wilde verdedigen, omdat dat zijn oogmerk alleen maar zou hebben verstoord. Toch maken de voorbeelden het een en ander duidelijk over het krachtenveld waarin de hedendaagse verdediging in strafzaken opereert, en de belangen die daarmee gemoeid zijn. Sleutelwoorden zijn daarbij: onpartijdigheid (vertrouwensrelatie), in het proces-Ceausescu pijnlijk afwezig, en deskundigheid (Socrates had er geen behoefte aan, mar wie kan zich mer hem meten?).

De rechtsbijstand in strafzaken is in ons recht en in onze rechtspleging hecht verankerd. Maar een rustig bezit vormt zij allerminst. Ik zal in het navolgende enkele problematische kanten ervan de revue laten passeren.

\section{Objectivering van de belangen van de verdediging}

De raadsman moet "de belangen van zijn cliènt" verdedigen. Maar welke zijn die belangen? En welke ruimte mag en moet de raadsman benutten om deze te verdedigen?

Niet alle belangen van de verdachte mogen in het strafproces worden verdedigd. Om de gedachten te bepalen kunnen worden onderscheiden:

in klassiek Athene. Diss. RU Groningen 1900 . De professionalisering was onstutbaar, mar riep ook weerstanden en wantrouwen op. 
- oirbare en onoirbare belangen. Voorbeeld van dit latste is het belang bij het verborgen blijven van de door middel van een door misdrijf verkregen buit.

- legitieme en illegitieme belangen.

Voorbeeld van het laatste: eindeloze vertraging van het strafproces, met de kans op verdwijnen van bewijs of overschrijding van de "redelijke termijn" (art. 6 EVRM).

De radsman mag stellig niet meewerken aan het veilligstellen van de eerstbedoelde categorie belangen. Maar het bevorderen van procesvertraging, of het verhogen van de kans dat door procedurele complicaties "vormfouten" worden gemaakt, als dat in het belang van de client is? $O p$ beide punten kom ik terug. Eerst wil ik nog de aandacht vestigen op de normativering en objectivering van de belangen van de verdachte of de verdediging, die door de rechtspraak wordt toegepast teneinde het recht zijn loop te doen hebben.

Een uit wet en rechtspraak bekend criterium is de vraag, of de verdachte al of niet in zijn verdediging is geschaad. ${ }^{4}$ Deze formule wordt gebruikt wanneer de rechter een schending van een vormvoorschrift constateert, maar deze niet van een zodanig gewicht acht dat nietigheid van het onderzoek, of in extreme gevallen zelfs niet-ontvankelijkheid van het Openbaar Ministerie moet volgen; of ook, wan-

${ }^{4}$ Vgl. T.M. Schalken, E.J. Hofstee, In zijn verdediging geschaad. Over vormverzuimen en het belang wan de verdachte. Bundel opstellen aangeboden aan prof mr.]. Remmelink bij zin afscheid als hoogleraar strafrecht an de Vrije Uniwersiteit. Arnhem (Gouda Quine), 1989. In zijn inleidende opstel, Schending van wetrelijke procesvoorschriften en her redelije belang wan de verdachte een redelijk criterum? Enkele inleidende opmerkingen, noemt Schalken HR 3 jamari 1989, NJ 1989, 515 : bet geconstatecte vertum heef de vordachte niet in zijn verdediging kumen schaden on makt ook nice in zodanige mate inbreuk op een goede procesorde dat nietigheid het gewolg behoort te zijn. Schalken leidt daaruit af, dat naast het (gerclativerdej belang van de verdachte ook een algemeen betang in het geding is, Zie ook de wettelijke formulering in art. 280 vierde lid 5 : op de lijst voorkomende getuigen dic niet zijn verschenen moeten tegen een mader te bepalen tijdstip worden gedigvard of schritulijk opgeroepen, tenzij de rechbark gemotweerd besist "dat door het achterwege blijven daarvan de verdache redelijkerwijs niet in ain verdediging kan worden geschaad'. Vgl. ook het zesde lid. Hierover in de genoemde bundel E.J. Hofstee, De getuige an de getuigenlijst, t.al.p., blz. 157-193. 
neer een bepaald verzoek (bijvoorbeeld tot het doen oproepen van getuigen) wordt afgewezen.

"In zijn verdediging geschaad" is een verkorte aanduiding van: geschaad in zijn oirbare en legitieme belangen, woorzover die bestaan in het onbelenmerd en volledig ütoefenen van de rechten die het strafprocesrecht hem toekent on zijn verdediging te voeren. Toch is het zo, dat de rechter die bepaalde verzoeken van de verdediging weigert, of vormfouten sauweert, de verdediging behoorlijk kan frustreren.

Het oordeel dat de verdachte geen belang heef bij het doen horen van bepaalde getuigen is heel 'tricky'. Zo'n beslissing neemt in feite een voorschot op de eindbeslissingen die het college zal moeten nemen op grond van artikel $350 \mathrm{Sw}$. Hetzelfde geldt, als de formulering wordt gebruikt: de rechtbank (het Hof) acht zich voldoende voorgelicht en heeft geen behoefte aan het horen van meer getuigen c.q. deskundigen.

In de eerste plaats moet worden vastgesteld, dat de verdachte in ieder geval wordt geschaad in de belangen, zoals hij deze subjectief definieert. Er is dus sprake van objectivering. De achterliggende, verzwegen redentring van de rechter in dergelijke gevallen zou ongeveer als volgt kunnen luiden: de verdachte meent nu wel dat de verklaringen die de door hem gewenste getuigen - ter zitting, of anders door de R-C te horen - zouden afleggen een ander, voor hem gunstig licht op de zaak zouden kunnen werpen, en wat zij zouden kunnen verklaren zou in principe nog wel ter zake kunnen zijn maar zou niets toevoegen noch iets afdoen aan het door het onderzoek tot dusverre reeds verkregen beeld. van de zaak, bijvoorbeeld ondat de getuigen reeds eerder zijn gehoord en de verdediging in de gelegenheid werd gesteld om vragen te stellen, en (of) vanwege het grote tijdsverloop sinds het telastegelegde feit plaatsvond.

Maar in de regel kan daar wel het één en ander tegenover worden gesteld. Zoals elk proces is het strafproces dynamisch. Het heeft ook iets van een kaleidoscoop: de verzamelde feiten kumen in elke volgende fase een heel ander beeld gaan vertonen. Dat kan ertoe leiden dat het opnieuw horen van reeds gehoorde getuigen, nog afgezien van het onmiddellijkheidsbeginsel, op zijn minst iets an de waarheidsvinding zou kunnen bijdragen. Strikt genomen is het praktisch onmogelijk on het tegendeel aan te tonen!

De objectivering geschiedt aan de hand wan normatieve gezichtspunten, 
ontleend wan de idee van de goede procesorde (wel te onderscheiden van de beginselen van behoorlijk strafpracesrecht!).

lk heb in relatie tot het zojuist gegeven woorbeeld het oog op het adagium 'lites finiri oportet'. Een proces moet niet eindeloos voortslepen, maar er moet op een gegeven moment een eind aan komen. In dit beginsel raken doelmatigheid en rechtmatigheid elkaar. Wanneer recht wordt gesproken in nam wan het wolk, heeft het volk er recht op dat een oordeel wordt gegeven, en wel binnen een redelijke termijn, en tegen redelijke kosten. Dat spreekt nog duidelijker wanneer sprake is van een individueel slachtoffer, diens familie, naasten, eventueel nabestaanden en dergelijke. Om emotionele maar ook financiële redenen moet er op een gegeven moment een rechterlijke uitspraak liggen. De raadsman kan zich daarom niet beperken tot het bewaken van een juiste wetstoepassing en het verduidelijken van de persoonlijke achtergronden van zijn cliënt. Hij moet ook voortdurend tegen de stroom wan de 'procesorde' oproeien. En dat in een situatie, waarin de rechterlijke macht personeel en logistiek onvoldoende is toegerust.

\section{Alertheid van de advocaat}

Deze gespannen situatie leidt ertoe, dat de raadsman goed moet uitkijken zijn kansen on de procesvoering te beinvloeden te grijpen. Laat hij bijvoorbeeld een gelegenheid lopen om bezwaar te maken of een verzoek te doen, dan zal zijn cliënt daarvan de dupe kunnen worden, omdat in een later stadium (bijvoorbeeld in beroep of cassatie) hem voor de voeten kan worden geworpen dat hij maar eerder iets had moeten ondernemen.

In dit kader is van belang het accent dar de rechtspraak in toenemende mate legt op de alertheid van de verdediging. Men kan niet zonder risico de kans, om een vroege fase van het proces het onderzoek te beinvloeden, laten lopen. De kans bestat immers dat men later als argument voor de afwijzing van een bepaald verzoek - bijwoorbeeld tot het oproepen van getuigen ter terechtzitting - deze passiviteit voor de voeten geworpen krijgt. Het belang, om deze getuige( $n$ ) op de zitting. aan de tand te woelen is er in zo'n geval wel degelijk, en wanneer het oproepingsverzoek wordt afgewezen is de verdachte derhalve wel degelijk 'in zijn verdediging geschaad' (aangenomen dat de beoogde 
getuige een relevante verklaring zou kunnen afleggen in het voordeel van de verdachte). Maar door stil te zitten heeft de verdachte bij wijze van spreken zijn recht verwerkt; zijn belang komt niet meer voor honorering in aanmerking.

Enkele recente voorbeelden daarvan. Art. 271 Sv bepaalt, dat tegen de verdachte die niet op de zitting verschijnt verstek wordt verleend. De Hoge Raad heeft uitgemaakt, dat de opvatting, dat dit verstek alleen mag worden verleend wanneer de verdachte niet kan worden verweten dat hij niet is verschenen, geen steun vindt in het recht: 'Geen rechtsregel verplicht de rechter om de wel aanwezige radsman in de gelegenheid te stellen de redenen van het niet verschijnen van de verdachte uiteen te zetten tenzij de raadsman daartoe het verzoek doet'.

Ander voorbeeld: bij raadsmanwisselingen kan de griffie in verwarring geraken met betrekking tot de vraag, wie nu eigenlijk als raadsman optreedt. In een geval waarin zich een raadsman had gesteld, maar een confrère een weekje later een bezwaarschrift had ungediend, besliste de Hoge Raad — afwijkend van de conclusie van zajn Advocaat-Generaal Lejjten - dat de rechtbank erop had mogen vertrouwen dat de laatstgenoemde raadsman, die bericht had ontvangen van het tijdstip van behandeling in raadkamer, zijn confrère daarvan op de hoogte zou stellen. ${ }^{6}$ Waaruit valt te leren dat een raadsman als een bok op de haverkist moet zitten, on ook zijn beroepsgenoten niet mag wertrouwen. Aan de andere kant valt op, dat de Hoge Raad hier in feite de advocatuur als zodanig opport om in het belang van de rechtspleging eer functionele samenwerking te onderhouden. Ontbreekt het daaraan, dan kan men geen verhaal gaan thalen bij de griffie.?

Een laatste voorbeeld. De rechter kan op grond van art. $37 \mathrm{~b}$ Wetboek wan strafrecht de terbeschikkingstelling met werpleging bevelen, maat dan moet er een gemotiveerd advies liggen van twee gedragskundigen van verschillende disciplines - waaronder een psychiater - - die de be-

5 Vg1. HR 1o oktober 1.989, DD 90.065. Zie voorts 0.m. HR 8 december 1987, NJ 1988,704. Als de tadsman het woord krijgt moet hij ook alles kunnen anvoeren wathem van belang lijkt: HR 22 maart 1988, NJ $1989,13$.

"HR 21 februari 1989, DD 89.290.

"Zie Gedragsregel 29: in het belang van de rechtzockenden on van de advocatutu in het algemeen strewen de advocaten nat cen onderlinge verhouding die berust op welwillend heid en vertrow wen. Hier zou toewocging wan de "interest of justice" (art 6 EVRM), het belang van de strafrechtspleging, op haar plaats zijn. 
trokkene ten hoogste en half jaar voor de anwang der terechizitting hebben onderzocht. De wetgever heeft hier een steek laten vallen door over het hoofd te zien, dat in het geval hoger beroep wordt angetekend, de zes maanden termijn kan zijn verstreken. In 1990 heeft de Hoge Raad in cen tweetal arresten deze lacune gedeeltelijk gevuld, door - uitvoerig motiverend - op de stoel van de wetgever te gaan zitten en de gevolgen van diens feilen enigszins op te vangen. ${ }^{8}$ De Hoge Raad hanteert, om met annotator Corstens te spreken, een dubbele fictic: in de eerste plaats wordt aangenomen dat de onderhavige termijnoverschrijding geen gevolgen heeft indien verdachte en verdediging er geen bezwaren tegen hebben, en in de tweede plaats wordt deze instemming aangenomen wanneer - zoals in het geval van het arrest NJ 1990, 517-het Openbaar Ministerie de tbs met verpleging heeft gevorderd en de advocaat, al is het meer in de vorm van een meer subsidiair verweer, heeft gepleit voor tbs met verpleging gecombineerd met een wrijheidsstraf gelijk aan de toegepaste voorlopige hechtenis.

In de zaak NJ 1990, 518 was wel uitdrukkelijk bezwar gemaakt door de verdediging (er was zelfs om contra-expertise verzocht), zodat daar werd gecasseerd en verwezen naar een ander Hof. Wanneer men als raadsman dus een vinger geeft, riskeert men dat de rechter gretig de hele hand pakt.

Tot zover over de druk die de hedendaagse strafrechtspleging op de advocaat in strafzaken uitoefent. Wij komen nu aan de centrale vragen toe, waarvan ik mar enkele puntjes kan aanstippen. Waarom is de rechtsbijstand in strafzaken door een rechtsgeleerde professional in een strafrechtspleging als de onze zo belargrijk? Welke normatieve kaders bepalen het werk wan de raadsman in de relatie met de cliënt en met de justitiele organen? Hoe ver mag en moet hij gaan bij het vervullen van zijn taak, ook tegenover derden-betrokkenen zoals het slachtoffer?

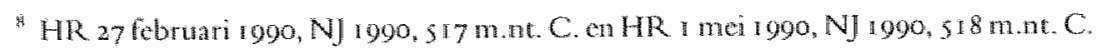




\section{Het belang van de verdediging}

De term "verdediging" staat voor de verdachte en zijn taadsman (soms: raadslieden). Dit an het militair sprakgebruik ontleende begrip veronderstelt het gebruik van de tegengestelde term: 'aanval', maar daarvan wordt voorzower ik weet nooit gesproken in het kader van het strafproces. De wet spreekt met van 'verdediging', maar van verdachte, of - in de cassatiefase - van requirant, en van de raadsman. Raadsman en verdachte zijn-hoe verschillend hun rol en posities in allerlei opzichten ook mogen zijn - in ons wettelijk systeem tot elkaar veroordeeld. Voorzover het gaat om het onderzoek ter terechtzitting wordt dit tot uitdrukking gebracht door artikel $33 \mathrm{r}$ eerste lid Sv: elke bevoegdheid die de verdachte is toegekend in Titel VI (behandeling door de rechrbank ter terechtzitting) komt ook toe aan diens raadsman. De ratio wan deze koppeling valt opmerkelijk genoeg niet in de wet te lezen. De formulering van de advocateneed in artikel 3 tweede lid Advocatenwet 1952 geeft voorzover het om de relatie met de cliënt - en dus de relatie raadsman - verdachte - gat slechts een negatieve anwijzing: "(..) dat ik geen zaak zal aanraden of verdedigen, die ik gemoede niet gelove rechtvaardig te zijn'. De tuchtrechtspraak moet het doen met de vage norm van artikel 46 Advocatenwet, waar onder meer sprake is wan de 'zorg die zij als advocaat behoren te betrachten' en van 'handelen dat een behoorlijk advocat niet betaamt'. De gedragsrege's 1980 , die overigens voor de tuchtrechter naar vaste rechtsprak geen bindende kracht bezitten, geven ook weinig houvast: regel 8 bevat het zorgvuldigheidsgebod ('De advocat behoort de hem opgedragen zaken zorgvuldig te behandelen'). De 'Ereregelen voor de advocaten 1968 waren iets uitvoeriger. De eerste twee leden van regel $4 \mathrm{I}$ luidden:

'1. De advocaat behoort alle hem opgedragen zaken - zonder onderscheid - met grote zorg te behandelen.

2. Bij de behandeling van zijn zaken dient de advocaat zich nimmer door zijn eigen belang, doch alleen door de rechtmatige belangen van zijn client te laten Jeiden'.

Het meest instructief is de Gedragscode voor de advocaten van de europese gemeenschap (Straatsburg, 1988). Regel 2.7 (belang van de cliënt) luidt: "Met inachmeming van de wettelijke regels en de gedragsregels is de adwocaat verplicht de belangen van zijn client zo goed 
mogelijk te behartigen, en dient hij deze zelfs te stellen boven zijn eigen belangen, die van een confrère of die van de beroepsgroep', terwijl regel 3.1.2. het woord "verdedigen" bezigt: "De advocaat zal met voortvarendheid, gewetenswol en met ijwer zin client adviseren en verdedigen"?

Uit deze citaten komt natar voren dat, wanneer men de belangen die door de verdediging in strafzaken worden gediend wavuit de beroepsethick van de advocatuur benadert, het belang van de werdachte prominent is.

En dat ligt voor de hand: in de setting van het strafproces is de verdachte de underdog, degene die wordt aangevallen (beschuldigd, aangeklaagd), en zich daartegen teweer moet kunnen stellen.

Bijstand van een ander, die niet zelf object van onderzoek en wervolging is en evermin anderszins (persoonlijk-emotioneel of financieel) geinvolveerd $\mathrm{kan}$ in een bedreigende confrontatie als een strafrechtelijke procedure voor de verdachte meestal is een belangrijke steun betekenen, en veelal een absolute voorwaarde zijn om een effectieve verdediging te voeren. Dat dic ander ook deskundig is, dat wil zeggen op de hoogte van de processuele rechten wan de verdachte en van de regels met betrekking tot de materieelrechtelijke normen en op te leggen sancties is uiteraard ook in het belang van de verdachte, zoals - last but not least - de volstrekte partijdigheid van de radsman en in nauwe samenhang daarmee de vertrouwensrelatie met die radsman toch vooral ten faveure van de verdachte strekken.

Maar daarmee is het verhal lang niet uit. In de inleiding bij de meergenoemde gedragscode voor de advocaten van de EG wordt over de taak van de advocaat het volgende gezegd: "In een nuatschappij, dic gegrondwest is op de ecrbied voor de gerechtigheid, heeft de advocat een vooname rol. Deze is niet beperkt tot het getrouwelijk uitvoeren van een opdracht binnen het kader van de wet. In een rechtsstaat is de advocaat onontbeerlijk voor de Justitic en voor de rechtzoekenden, wier rechten en wrijheden hij moet verdedigen; hij is zowel de raadsman als de verdediger van zijn cliènt".

Hier komt een ander belang aan bod: het algemeen belang. De raads-

"Zic voor de teksten van de gedrags- en ereregels en de CCBE-code, G.P.M.F. Mols, Vivian Malherbe, Tuchrechrspraak voor advocaten, Nederlandse orde wan Advocaten. Zwolle (W.E.J. Tjeenk Wilink), 1990. 
man is onontbeerlijk voor de rechtspleging, niet alleen voor de verdachte! Het kan ook wat algemener worden gesteld: dat de verdediging op een behoorlijke manier kan worden gevoerd is een algemeen belang. De erkenning daarvan ligt ook ten grondslag van artikel 6 Europees verdrag tot bescherming van de rechten van de mens en de fundamentele vrijheden, dat trouwens in zijn derde lid enkele malen de term "werdediging" bezigt (de burger moet kunnen beschikken over voldoende tijd en faciliteiten ten behoeve vam zijn verdediging; hij heeft het recht zichzelf te verdedigen dan wel zich te doen bijstaan door een gekozen raadsman, en als hij die nier kan betalen door een toegevoegde, door de staat betaalde raadsman).

Naar nationaal en international recht is het recht op verdediging niet alleen een papieren zaak (zie bijvoorbeeld artikel i 8 van onze Grondwet), maar komt het ook in de rechtspraak uit de verf. Allereerst een nationaal voorbeeld.

Een illustratie van de norm, dat de verdediging met een beroep op de 'eenvoudigheid' van de zaak niet zonder meer kan worden terzjjde gesteld is te vinden in een recente $\mathrm{HR}$-uitspraak over artikel $\$$ r tweede volzin Sv: 'Van alle stukken, die ingevolge dit wetboek ter kennis van de verdachte worden gebracht ontwangt de radsman onverwijld afschrift'. In 1986 wordt aan iemand die van enkele misdrijven wordt verdacht en tegen wie de bewaring wordt bevolen, door de president van de rechtbank een raadsman toegevoegd. Enkele maanden later ontvangt hij voor deze misdrijven een kennisgeving van niet verdere vervolging, met mededeling dat hij voor een Vuurwapenwetmisdrijf te zijner tijd zal worden gedagvaard. In januari 1988 ontvangt hij de dagvaarding voor de politierechterzitting van 5 februari. Tegen I februati meldt hij zich bij zijn raadsman, die uitstel van de behandeling ter zitting verzoekt omdat hij "verhinderd is de verdachte te vergezellen'. De verzochte aanhouding wordt niet verleend ondat de dagvarding reeds op 18 januari 1988 in persoon was vitgereikt, en onder die omstandigheid het feit "dat de raadsman wan werdachtes keuze niet ter terechtzitting aanwezig heeft kunnen zijn" voor verdachtes rekening moet blijwen, 'te meer waar deze zaak de Politierechter als van eenvoudige aard voorkomt en een aanhouding zich slecht verstaat met een juiste en tijdige berechting van de zaak'. De zaak wordt dus zonder raadsman ten gronde behandeld; en wel in twee instanties. De HR stelt 
vast dat de Politierechter heeft miskend dat de raadsman in kwestie niet wen te elfder ure gekozen raadsman was, maar reeds in 1986 werd toegevoegd. Hem had daaron op grond van artikel $5 \mathrm{I}$ Sv een afschrift van de dagvaarding moeten zijn toegezonden. De HR overweegt dan: 'Het in het belang van de verdachte gegeven voorschrift vervat in de tweede zin van art. 5 I Sv is van zo grote betekenis dat, al wordt zulks niet uitdrukkelijk in de wet bepaald, de niet nakoming daarvan geacht moet worden aan een geldige behandeling ter terechtzitting in de weg te stan tenzij, in het geval dat de verdache en/of zijn raadsman niet zijn verschenen, a) door de rechter in redelijkheid $k a n$ worden aangenomen dat de verdachte er geen prijs op heeft gesteld ter zitting te verschijnen en/of door zijn raadsman te worden bijgestaan, of wel b) de rechter het onderzoek ter terechtzitting schorst ten einde 'zulks in overeenstemming met art. 6 derde lid sub b en sub c EVRM-verdachte en zijn radsman de gelegenheid. te geven zich voldoende voor te bereiden en beveelt dat alsnog aan de radsman een afschrift van de betreffende dagwaarding wordt toegezonden". "Volgt vernietiging en verwijzing, omdat het Hof het vonnis wan de politierechter had moeten vernietigen met terugverwijzing, zodat de verdachte de mogelijkheid van een berechting in twee instanties, met volledig respect voor de fair trialgedachte, niet door de neus zou zijn geboord.

Dan een voorbeeld, ontleend aan de Europese rechtsprak.

In het door de HR in zijn bovenvermelde arrest aangehaalde art. 6 derde lid sub c EVRM krijgt de burger "charged with a criminal offence" het recht toegekend "to defend himself in person or through legal assistance of his own choosing or, if he has not sufficient means to pay for legal assistance, to be given it free when the interests of justice so require'. Die belangen van de rechtspleging (want zo luidt de nieuwe

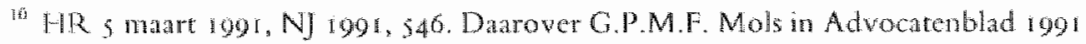
(nr, 9), ble. 255 e.8. Ziewoorts o.m. HR 23 oktober $1980, N J 1987$, 45, maar ook HR 26 januari 1988, NJ 1988, 1022. Soms probeert de rechter het vormverzum te herstellen doot een zeer korte schorsing toe te stan, bijv. van ech ubr, zodat de zak op dewelfe zittingsdag kan worden afgedaan. Dartegen behoefe geen bezwar te bestain wanneer de zak overzichtelyk genoeg is en her belang van do verdache is gediend met spoedige afhandehng. Mar wanneer de verdediging bexwar makt zall zich un.i. niet gauw een situatie voordoen warin zo"n superkorte schorsing het werzuim zal dekken. 
Nederlandse vertaling; vroeger was het rechtspraak) noemde ik al. Wat houdt dit begrip in? In een recente uitspraak in de Quaranta-zaak heeft het Europees Hof voor de Rechten van de Mens de criteria geformuleerd waraan moet worden getoetst, wil men deze vraag juist beantwoorden." In de eerste plats moet de emst van het delict in aanmerking worden genomen, en de aard wan de straf die hij riskeerde (het ging om een narcotica-delict, waarop volgens de Z $Z$ whitserse wetgeving een vrijheidsstraf en geldboete staan). Volgens de Zwitserse regering was er in het dossier geen indicatie voor cen straf van meer dan I8 maanden, het maximum voor een schorsing van de straf op grond van art. 4 I van het $Z$ witsers wetboek van strafrecht. Met de oplegging van 6 maanden gevangenisstraf was de rechter ruimschoots beneden die limict gebleven, zelfs wanneer men de tenuitvoerlegging van een in 1982 opgelegde geschorste gevangenisstraf van to maanden erbij telde. Het Hof merkt daarover echter op, dat het hier slechts om een schatting gaat: "the imposition of a more severe sentence was not a legal impossibility'. Quaranta riskeerde maximaal 3 jaar gevangenisstraf. De conclusie van het Hof is loud and clear: "In the present case, free legal assistance should have been afforded by reason of the mere fact that so much was at stake'. Een tweede factor thet arrest spreekt van 'an additional factor'; de eerstgenoemde factoren zijn kennelijk de belangrijkste!) is de ingewikkeldheid van de zaak. De Zwitserse regering had aangevoerd, dat het onderzoek naar de feiten in deze zaak vrij simpel lag, te meer omdat klager tegenover de onderzoeksrechter on middellijk had bekend het telastegelegde te hebben begaan. Mar, aldus het Hof, het resultaat wan de zaak was voor klager zeer belangrijk omdat hij in een proeftijd liep, zodat niet alleen over de zaak zelf, maar ook ower de tenuitvoerlegging van een oude, geschorste straf moest worden beslist. 'The participation of a lawyer at the trial would have created the best conditions for the accused's defence, in particular in view of the fact that a wide range of measures was available to the Court'. Deze kwesties, op zichzelf al ingewikkell genoeg, werden voor klager nog gecompliceerd door zijn persoonlijke omstandigheden (vreemde afkomst, geen beroepsopleiding, lange straftijst enzovoort). Om die redenen had hem bij

"Case of Quaranta v. Switzerland, 24 mei 1901 (23/1990/214/270), rechtsowerwegingen 33 , 34 . 
de behandeling voor de onderzoekstechter en vervolgens voor de rechtbank niet een advocaat mogen worden onthouden.

Wanneer de nationale wetgeving aan de rechter of de administratie een discretionaire bevoegdheid toekent tot toevoeging wan een raadsman, moeten volgens deze uitspraak dus de volgende criteria worden aangelegd:

- is het feit waarvoor wordt vervolgd ernstig?

- zijn de mogelijkerwijs op te leggen sancties zwaar?

- is de zaak ingewikkeld? Dit criterium kent drie facetten:

a. de feirelijke toedracht,

b. op te leggen sancties, ook in verband met complicaties zoals de tenuitvoerlegging van oude, voorwaardelijke (geschorste) vonnissen;

c. persoonlijke omstandigheden van de verdachte. ${ }^{12}$

Vermelding verdient hier nog de administratieve toevoegingspraktijk van de Bureau's voor rechtsbijstand (formeel, in afwachting van de invoering van een Wet op de rechtshulp, nog steeds de Raad voor rechtsbijstand in strafzaken op grond wan artikel 76 tweede volzin Advocatenwet) aan verdachten van een overtreding. Op grond van de Leidraad bij het toevoegen in civiele en strafzaken $1985^{13}$ geldt bij strafzaken die in eerste aanleg door de kantonrechter worden behandeld als uitgangspunt, dat niet wordt toegevoegd tenzij zich één van de navolgende omstandigheden voordoet:

I. het is redelijkerwijs te verwachten dat een vrijheidsstraf zal worden gevorderd;

13. Ziv voor een overzich van de rechtsprak wan de Europese Commissie voor de Rechten van de mens an het Europerc Hor voou de Rechten wan de Mens met betrekking tot de rechten op en wan deverdediging (art. 6 derde lid onder $\mathrm{c}$ in relatie met art 6 cerse lid). P. van Dijk, G.J.H. wan Hoof, De Europese Conventie in theorie en praktijk. Nijmegen (Ars Aequi Libri), 1990 (derde druk), bliz. 385-390. Vgl. ook art 14 derde lid onder $b$ en onder d International Verdrag inzake burgerrechten th politioke rechten.

13 Dowe Leidrat is opgesteld door de Landeljke vereniging van medewerkers van Buro s voor rechtshulp (LOK). Zie ower de juridische status van deze circulaire AR Ralad van State 15 maart 1988, Administratiefrechtelijke Beslissingen 1.989, $1 \mathrm{I} 2$ m.nt. W. varu der Nat-Werhage; vgl, ook Delikt en Delinkwent (rubrick advocathar) 19 (1989), blz. 693 . 
2. er zal waarschijnlijk een in relatie tor het inkomen van de verzoeker hoge boete worden gevorderd;

3. er zijn relatief grote civielrechtelijke belangen in de zaak betrokken;

4. de zaak is juridisch of feitelijk gecompliceerd;

5. het te wijzen vonnis zall van principiele betekenis kunnen zijn, dan wel matschappelijk van groot belang.

Er zitten twee kanten aan de zaak van de belangen van de verdachte en de verdediging. Aan de ene kant is de vraag: kan de verdachte zich door een advocaat doen bijstaan (zelfs als hij er niet voor kan betalen)? Aan de andere kant gaat het om de vrag, of de verdachte het recht heef zichzelf te verdedigen, of zich moet laten vertegen woordigen (en zo ja, of dat door een professionele verdediger moet geschieden). Over de eerste vraag gaat het Quaranta-arrest. Wie dat wenst, heeft recht op professionele bijstand "if the interests of justice so require". De tweede vraag is een geheel andere kwestie, die raakt aan wat men zou kunnen noemen het 'democratische' of 'open' karakter van de strafrechtspleging, en de mondigheid van de verdachte en de burger/rechtsgenoot in het algemeen. Uit art. 6 derde lid onder c EVRM vloeit niet rechtstreeks voort dat de verdachte het recht heeft on zelf de verdediging te voeren; wel, dat wannee het nationale recht of de nationale. justitiële autoriteiten bepalen dat de verdachte zich door een advocaat moet laten bijstaan, hij ook bij financieel onvermogen een advocaat moet kunnen krijgen (liefst ook van zijn eigen keuze, maar dat is - nog - geen 'hard' recht). Die rechtsbijstand 'wordt dan immers kennelijk door het nationale recht respectievelijk de justitiële autoriteiten noodzakelijk geacht in het belang van de rechtspraak', aldus Van Dijk en Van Hoof in hun handboek over de Europese Conventie. ${ }^{14}$

In cassatie bijvoorbeeld kan de verdachte - in die fase inmiddels gepromoveerd tot requirant - niet zelf het woord voeren ter openbare terechtzitting. ${ }^{15}$

1. T.a.p., b.z. 387 .

$15 \mathrm{Vgl}$. art. $439 \mathrm{Sw}$ : Na de woordrache van het werslag wordt de radsman van de verdachte de gelegenheid gegeven on het woond te woeren'. Er stat niet, dat de requirant niet het woord mag woeren, maar dat wolge wel uit de systematick wan het wetbok, dat steeds uitdrukkelijk angeeft wie wanneer ter zitcing het woord mag voeren. 
Er wordt tegenwoordig stevig gedebatteerd over mogelijkheden de zakenvloed naar de cassatierechter in te dammen, waarbij onder meer de suggestie van een op strafte van niet-ontvankelijkheid verplichte cassatieschriftuut is gedaan (nu slechts bekend in art. 56 eerste lid WED). Daarbij zou invoering van 'advocatendwang' passen, de verplichte indiening door cen radsman. Zo wordt de weg naar het recht voor de burger steeds minder overzichtelijk.

\section{Deskundigheid en cliënt als dominus litis}

Hiermee is een belangrijk aspect van de relatie tussen de (deskundige) raadsman en de cliënt aan de orde. Alieen een Socrates kon zonder advocaat een proces tot op zekere hoogte naar zijn hand zetten. Maar de meeste burgers zullen niet zo sterk in hun sandalen staan als deze wijsgeer. De inschakeling wan cen deskundige betekent-behalve hulp - ook een probleem erbij: gaat de deskundige niet met mijn belangen op de loop? Hoe houd ik hem aan het lijntje?

Een aanvardbaar - maar daarom nog niet noodzakelijkerwijs doorslaggevend - motief om de raadsman een bevoegdheid toe to kennen die zijn cliënt niet heeft-de bevoegdheid om in cassatie ter zitting het woord te voeren - is gelegen in de veronderstelde deskundigheid van de raadsman. De wetgever gat er vanuit, dat de mondelinge inbreng van de radsman functioneler is dan die van de requirant. Of men met die keuze primair het belang van de requirant op het oog heeft gehad is de vraag. Men kan natuurlijk aanvoeren, dat het mede in het belang van de requirant is dat in een fase van de procedure, warin het weelal bij uitstek gat om gecompliceerde, technisch-juridische problemen, hij zijn zaak wel eens zou kumnen bederven wanneer hij zelf het woord zou voeren. Daar zit zeker iets in. Maar zwaarder weegt

16. Voo en kritische bespreking van de diverse voorstellen, zive J, de Hullu, Over rechtsmiddchen in strafaken. Amhem (Couda Qwint), 1989, bla, 39 i c.v., blz. 240 e. v. en over de vorhoopre, natar m.i. kwesticuze filterfuncte wan de balie alsmede de wenselijkheid wan oen verlofstelsel in cassate G.J.M. Corstens, beperking van de cassaticrechtsprak in strafaken, in: Herziening rechterlike organisatio, Verslag van het Symposium van 22 juni 1990 georganiseerd door de Faculteit der Rechtsgeleydheid Katholicke Universiteit Njmegen in samenwerking net de Stichring Studiecentrum Rechespleging. Zwolle (Tjeenk Wilink), ble. 165-176. 
toch "the interest of justice" - het belang van de rechtspleging. Vanaf het moment dat de aanwezigheid wan de verdachte als voorwerp van onderzoek niet meer nodig is, gaat het nog slechts om zijn eventuele aanwezigheid als partij. Welnu, in die hoedanigheid ligt vertegenwoordiging door een deskundige voor de hand, en heeft - zeker waar het gaat om het mondelinge deel van de procedure - een efficiencyverhogend effect. Evenals de ervaringen in het uitleveringsproces leerden, vergt het veel rechterlijke energie om de betrokkene (in dat geval de opgeëiste persoon) uit te leggen dat zijn schuld of onschuld, bewijskwesties en dergelijke niet, althans niet op dezelfde manier an de orde zijn zoals in een "gewoon" strafproces. Dat neemt niet weg, dat het wel heel ver gaat degene, om wie het allemaal begonnen is - het beoogde object van strafrechtelijke sanctionering - op een gegeven moment in de procedure buiten spel te zetten voornamelijk om redenen van efficiency, en niet bijwoorbeeld in het belang van het onderzoek (dit latste is onder andere het geval bij het horen van getuigen in het vooronderzoek). Men ziet hier de raadsman in de rol van functionaris van de rechtspleging: hij doet immers iets wat zijn cliënt thiet kan. De keerzijde van deze optic is evenwel, dat de vertrouwensrelatie met zijn client onder druk komt te staan. In de praktijk valt dat misschien wel mee, maar het is onmiskenbaar een complicatie in de verhouding advocaat - cliënt, vergelijkbaar met de procureursdwang in burgerlijke zaken. $^{17}$

'Het is in het Nederlandse strafproces aan de kant van de verdediging de verdachte - en niet de raadsman - die als dominus litis optreedt". Hoe verhoudt deze kloeke stelling zich tot regel I 2 van de Gedragsregels 1980 ? De eerste twee leden daarvan luiden als volgt:

'1. De advocaat heeft ook tegenover zijn cliènt de leiding der zaak. maar mag geen handelingen verrichten tegen de kennelijke wil van zijn cliènt. Hetgeen door hem wordt verricht geschiedt onder zijn verantw

VZie o.a. art. 133 en art. 138 Wetboek van burgerlijke nechtsvordering. Vgl. G.R. Rucgers, De verplichte procesvertegenwoondiging: enige aspecten wan de vetplichte procesvertegenwoordiging in het burgerlijk geding in Nederland. "s-Gram wenhage (VUGA), 1980 .

13 Aldus A.L. Melai, Het strafgeding: polariteit en tegensprak, lniciding van A.L. Melai c.s. Het Wetbock wan strafvordening (losbl.). Amhen (Gouda Quint) blz. 159. 
woordelijkheid, watatan hij zich niet kan onttrekken met een beroep op de van zijn cliênt verkregen opdracht.

2. Indien tussen de advocaat en zijn cliënt verschil van mening bestaat over de wijze warop de zaak moet worden behandeld en dit geschil niet in onderling overleg kan worden overbrugd, dient de advocaat zich terug te trekken". Hebben wij hier met een tegenspraak te maken? Dat geloof ik met. Het begrip "dominus litis" is te vaag om die vraag bevestigend of ontkennend te beantwoorden, en hetzelfde geldt woor de term 'leiding der zaak'. De ereregelen 1968 hanteerden naast deze term ook de term "dominus litis". Bij de gedragsregel gatat het er uiteraard niet om, dat de advocaat de baas is en de cliënt zijn leiding maar heeft te anvaarden (hetgeen het toppunt van paternalisme zou zijn), maar om tot uitdrukking te brengen dat de adwocaat die een scheve schaats rijdt zich achter zijn cliënt zou kunnen verschuilen. Om zijn taak naar behoren te vervul] Jen dient de advocaat op zijn eigen oordeel af te gaan, en zijn onafhankelijkheid ook tegenover zijn cliënt te allen tijde te bewaren. Dat wordt beter dan in de huidige gedragsregels geformuleerd in de door de Commissie Herziening Gedragsregels van de Nederlandse Orde van Advocaten (de commissie-Bitter) voor te stellen tekst, waar de term 'leiding der zaak' is geschrapt: 'De advocaat draagt volledige verantwoordelijkheid yoor de behandeling van de zaak'. In deze verbeterde versie is de regel ook in strafzaken zinvol, wanneer men maar bedenkt dat onder 'behandeling van de zaak' slechts die verrichtingen kunnen vallen die de raadsman als vertegenwoordiger van zijn cliënt verricht. Daaronder vallen de zaken waarin de raadsman (overigens niet exclusief; het deskundigheidsaspect speelt hier geen rol omdat het in het algemeen om eenvoudige en niet ernstige zaken gaat) als gemachtigde optreedt (art. 270 Sv, art. 398 eerstelid Sv), en het namens de verdachte dan wel de requirant aanwenden van rechtsmiddelen, het indienen van bezwaar-en klaagschriften, verzoeken, alsmede alle correspondentie, telefoongesprekken, vragen aan getuigen en deskundigen tijdens het vooronderzoek en ter zitting, en uiteraard het optreden tijdens de zitting. In het strafproces is het, meer dan in het burgerlijk en administratief proces, regel dat de verdachte er niet aan ontkomt zelf

Frergelen voor de advocaten 1968 , regel 27 eerste lid: "De advocat dient te bedenken, dat hij ook tegenover zijn diënt de leiding der zak heeft de behouden-dat hij dominus litis is - 'enzovoort. 
zijn zaak te "behandelen", waarbij hij zich in de regel kan doen bijstaan door een of meer raadslieden (vgl. art. $28 \mathrm{~Sv}$ ). De vrijheid die de verdachte is gelaten om zijn proceshouding te bepalen zal hij zelf moeten benutten; zijn raadsman kan daarbij alleen maar adviseren. Ook afzijdigheid (zwijgen, of zelfs niet verschijnen) komt neer op het bepalen van een proceshouding.

De verdachte-cliënt wordt dus als mondig beschouwd en behandeld. De raadsman $\mathrm{kan}$ in het algemeen geen proceshandelingen woor hem waarnemen, wat iets anders is dan namens hem uitvoeren. Maar uit het systeem van het Wetboek volgt wel degelijk, dat van de raadsman een forse brok 'ongelijkheidscompensatie' wordt verwacht, en dat het wel heel bar moet zijn gesteld met de verdachte, wil de procedure worden geschorst. De Hoge Raad interpreteert art. $16 \mathrm{~Sv}$, inhoudend dat indien de verdachte aan een zodanige gebrekkige ontwikkeling of ziekelijke stoornis van zijn geestvermogens lijdt dat hij niet in staat is de strekking. van de tegen hem ingestelde vervolging te begrijpen de vervolging wordt geschorst, niet ruim: er moet van een duidelijk pathologische storing sprake zijn. ${ }^{20}$ Het gaat er bepaald niet on, dat de verdachte de juridische of zelfs maar feitelijke portée van de tegen hem ingestelde vordering moet kunnen overzien en doorzien. Als het even kan geldt het devies: the show must go on. Dat blijkt ook uit de regeling van art. soga tot en met jogd Sv. In het uiterste geval kan op grond van deze regeling tegen een psychisch gestoorde verdachte buiten zijn aanwezigheid ter zitting worden voortgeprocedeerd. De raadsman, wiens instemming wel imperatief is voorgeschreven, blijft in dat geval met de verdediging belast (art. $509 \mathrm{c}$ Sv). ${ }^{21}$ Hier kan zich dus het geval voordoen dat de raadsman geheel naar eigen inzicht moet bepalen wat het belang van zijn cliënt dicteert.

Nog iets verder gaat in dit opzicht de regeling voor minderjarigen beneden de zestien jaar. Op grond van art. 504 eerste lid Sv komen alle bevoegdheden, aan de verdachte van deze leeftijdscategorie toegekend met uitzondering die bevoegdheden die hij ter terechtzitting heeft 'met

Zie bv. HR 5 februari 1980, NJ $1980,104$.

2) Over deze regeling die deels strijdig is met art. 6 EVRM, Ch. Hafmans, De berechting van de psychisch gestoorde delinquent. Handleiding voor juristen bij vraagstukken op het raakwlak van strafrecht en psychiatrie. Anhem (Gouda Quint) 1989, blz. I15-116. 
witsluiting van hemzelf toe aan zijn radsman'. Met betrekking tot het al dan niet aanwenden wan rechtsmiddelen geef het tweede lid een soort conflictenregeling, waarvan niet de verdachte, maar alleen zijn wettelijk vertegenwoordiger gebruik mag maken. Deze paternalistische uitwas zal in de nabije toekomst verdwijnen. "Als uitgangspunt is, dat de verdachte de vorm en het karakter van zijn werdediging bepaat en daarin wordt bijgestaan door zijn raadsman, is er op zichzelf geen reden voor het stellen van cen leeftijdsgrens', aldus terecht Verpalen. ${ }^{22}$

Men ziet: de wet gaat uit van de fictie, dat elke verdachte in stat is (enkele uitzonderingen daargelaten) zelf zijn verdediging te voeren. On de kloof met de werkelijkheid niet te groot te laten worden is de bijstand van een rechtsgeleerd raadsman een geintegreerd bestanddeel van het systeem.

\section{De laverende raadsman}

Tot zover besprak ik de relatie raadsman-cliënt. De advocaat in strafzaken treft echter nog andere 'obstakels' op zijn route. Hij moet beschikken over een stuurmanskunst, die hem in staat stelt te laveren tussen de Scylla van de verdachte en de Charybdis van $O M$ en rechter (om het niet te ingewikkeld te maken laat ik zwerwende rotsen, zoals medeverdachten, buiten beschouwing). Dat is natuurlijk een gevaar-

32 M.J.M. Verpaten, Het strafprocesrecht woot jeugdigen. Arnhem (Gouda Quint) I991, blz. 260 (ook opgenomen in A.L. Mclai c.s, Het wetboek van strafvordering, losbl. Ambem (Gouda Quint), commentaar op art. 504 Sy), Verpalen kan het ondersheid tussen de bevoggtheden tijdens en buten de terechtzitting nog wel billyken: de betrokkenheid wan de verdachte bij de zak make "dat een (cerste)

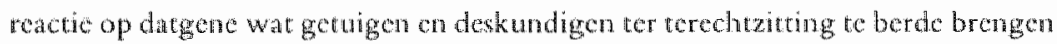
eender van hem dan van zijn raadsman te verwachen is" (t.a.p.). Ik denk daar anders over. Her zal toch wak zo zijn, dat juist de directe confrontate wjdens de rerechtzittheg makkt, dar bepalde verrichtingen - ik denk daabij vooral an het ondervagen van getuigen - extra lastig worder. Zij zijn zelfs woor advocaten, die dar zeer ten onrechte niet woor worden opgeleid, hecl moeilijk, late stan voor ecn jeugdige die zelf woorwerp van het gebeuren is. Wanneer je crgens behoefe hebt an cen gedistancicerde beoordeling (naast alerte betrokkenheid whteraard), is het wel ter terehtzitting. Wetsontwerp $2132 \%$, dat het strafprocesrecht voor jeugdigen grondig wizigt, rekent af met art $5 \mathrm{O}_{4} \mathrm{~Sv}$ in zijn huidige vorm. Voor kritiek op de voorgestelde tegeling, zie Verpalen, ta.p., ble. 58 en 275 . 


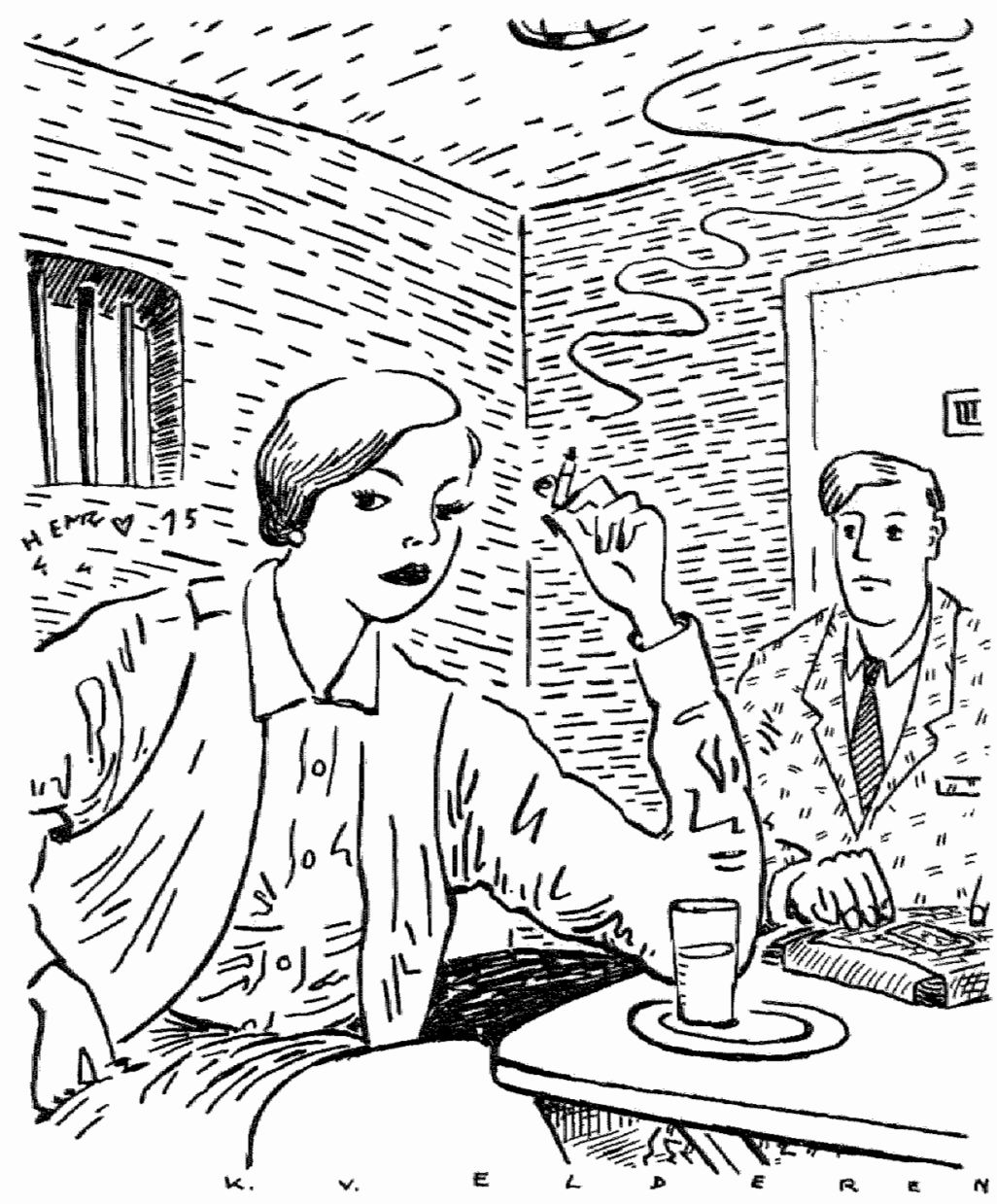

$1_{\text {ee, }}$ het was beter hem niets te vertellen omtrent de bij de roofoverval verkregen buit.

Dat zou hem in een ernstis gewetensconflict Kunnen bre Jigen en dat was het Jaatste wat zij de aardige en integere pro deo-advokaat şunde. 
lijke metafoor, omdat ik zojuist betoogde dat de raadsman partijdig is en dus aan de zijde van de Scylla zou moeten koersen. Ik bedoel, dat de raadsman aan de ene kant het gevaar loopt om te worden geidentificeerd met zijn cliënt, hetgeen in sommige, gelukkig vrij uitzonderlijke situaties zelfs tot criminalisering van de advocaat kan leiden, terwijl hij anderzijds moet oppassen niet door de justitiele instanties te worden ingekapseld. Deze gevaren vallen niet te bezweren door op safe te spelen; ook in de rechtshulp is dat het prerogatief der middelmatigen.

In de geruchtmakende strafzaken in de zeventiger jaren tegen de belangrijkste leden van de Rote Armee Fraktion (Baader, Meinhof, Meins en anderen) werd het advocaten emstig aangerekend dat zij meehielpen een communicatiesysteem tussen de gevangenen (niet alleen hun eigen cliënten) te onderhouden. Ties Prakken en Han Janse de Jonge verdedigden deze werkwijze, die sommige Duitse advocaten op tuchtrechtelijke en strafrechtelijke sancties was komen te staan (Croissant, Groenewold), als een in beginsell volstrekt legitieme en ook noodzakelijke vorm van politieke verdediging, Van Haersolte vond dat de raadslieden te ver waren gegaan. Op redelijk veilige (tijds)afstand van dit gebeuren en deze discussie stel ik vast, dat het bevorderen, dat de cliënt zijn morele (eventueel ook politieke) identiteit in het proces onbelemmerd kan tonen, tot de belangrijkste taken van een raadsman behoort. Als de cliënt daartoe zijn verdediging collectief wenst voor te bereiden en wenst te profiteren van de inbreng wan anderen - vervolgd, gedetineerd of niet - dan moet de raadsman in beginsel aan het leggen van die contacten meewerken. De mogelijkheid dat hij voor andere, illegale doeleinden kan worden gebruikt doet an die plicht niets af; het bevestigt slechts de indruk, dat het werk van de advocaat in strafziken soms hachelijk en moeilijk is. ${ }^{23}$

23 Han Janse de Jonge, Thes Prakken, Politieke verdediging: een rechtsstatelijk dilemma, in: NJB 1978, blz. 325-340. Darop kwam een reactie wan R.A.V. Wan Haersolte, Politieke verdediging ... in rechte, in: NJB 1978, ble. 609-605. Warna nog van de auteurs en Repliek, in: NJB 1978 , bl2. 605-607. Over deze rechtsataken de rijk-gedocumentecrde dissertatic van Pieter Herman Bakker Sichut, Politische Verteidigung in Strafsachen. Eine Fallstudic des won 1972 - 1977 in der Bundesrepublik Deutschland Gefuhrten Strafwerfahens gegen Andreas Baader, Gudrum Ensslin, Ulrike Meinhof, Holger Meins, Jan Carl Raspe, Kiel (Neuer Malik Verlag) 1986. Vgl. ook mijn pread wies voor de jaarvergadering van de Nederlandse Orde van Advocaten te Roemond, 198 s: Advocat, cliënt en politick, in: Advocatenblad 1985 (nr. 15), blz. 349-359. 
Evenzeer is het onvermijdelijk, dat zaken worden gedaan met de autoriteiten. De marge die de raadsman daarvoor heeft wordt aangegeven door de rek die in de vertrouwensrelatie zit. Sommige situaties moeten worden vermeden. Terecht keert Prakken zich tegen de suggestie van Myer om anonieme getuigen door de zittingsrechter te laten horen in het bijzijn van de advocaat maar zonder de verdachte, waarbij de advocaat aan een zwijgplicht zou worden onderworpen. ${ }^{24}$ Daarmee, zegt Prakken, 'wordt een wig gedreven tussen advocalat en cliënt, omdat de advocaat dan over kennis beschikt die hij niet aan zijn cliënt mag meedelen'. Daar mag een advocaat inderdaad niet aan meewerken. De door Prakken in hetzelfde artikel gewraakte praktijk, dat de verdachte niet zelf bij getuigenverhoren door de R-C wordt toegelaten maar aangewezen is op de diensten van zijn raadsman is al bedenkellijk genoeg..$^{25}$

\section{Aanval en verdediging: partijen in het geding?}

Het strafproces op tegenspraak (geding) veronderstelt partijev. Kan de verdediging worden beschouwd als "partij", op dezelfde voet als het Openbaar Ministerie? Cleiren voert tegen de kwalificatie van de verdachte als procespartij een bezwaar aan dat zijzelf 'uitermate belangrijk' noemt: $:^{26}$ de relatie tussen de 'deelnemers" aan het strafproces kan im-

24 Ties Prakken, Verdediging: hoezo equality of arms? in: NJB 1990, blz. 892, en E. Myer, Kostowski en de namloos gebleven getuigen (2). NJCM-bulletin r 990 , blz. 371.

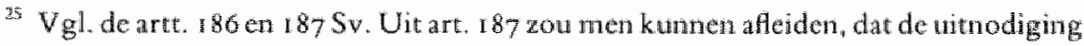
van de verdachte in beginsel verplicht is wanneer de bewuste getuige niet op de terechtzitting zal kunnen komen. De wet gatt dus uit van en dubbele controle door de werdediging wan het getuigenbewijs: cén mal door de raadsman bij de R-C; werwolgens (desgewense) nog eens ter zitting door de verdachte én door de taadsman. De praktijk is echter, zoals Prakken (t.a.p., ble. 892) signaleert, dat 'valk. geweigerd wordt getuigen ter zitting op te roepen ondat ze zijn gchoord door de recher-commissaris".

27. C.P.M. Cleiren, "Een grensoverschrijdende verdachte?" in: Grensowerschrijdend strafrecht. Een bundel opstellen geschreven door medewerkers van de afdeling straf(proces)reche, Rijksuniversiteit Leiden. Amhem (Gouda Quinc), r990, blz. I 4 I-164, m. m. bliz. 149 . 
mers - anders dan in het burgerlijk proces - niet als ean wederkerige rechsbetrekking worden angeduid. Wanneer de overheid tot strafvervolging overgaat, daartoe gerechtigd ondat aan de voorwarden van art. $27 \mathrm{~Sv}$ is voldaan (er is een redelijk wermoeden dat een strabaar feit is begaan), zou de relatie tussen overheid en verdachte volgens Cleiren toch eenzijdig zijn, omdat de verdachte, zeker in de overwegend inquisitoire voorfase van het proces, in sterke mate object van onderzoek en eventueel dwangmiddelen is. Daarop valt inderdaad niets af te dingen, mar toch is de term partij niet zo gek gekozen, omdat noet worden bedacht dat de verdachte niet alleen "verdachte" maar steeds ook lid is van de rechtsgemeenschap. Tenslotte gat het ook in strafrechtelijke procedure om een beweerd recht, dat kan worden betwist, en dat slechts kan worden geldend gemaakt wanneer aan een reeks normatieve voorwaarden is voldaan. Een rechtsfiguur als de transactie (art. $74 \mathrm{Sr}$ ) is ook alleen maar begrijpelijk op grond van een veronderstelde onderhandelingspositie, die op haar beurt weer min of meer gelijkwaardige - wat evenmin als in het civiele recht behoeft te betekenen: gelijke of gelijksoortige - partijen. ${ }^{27}$

Dat onder de procesdeelnemers de rechter geen partij genoemd moet worden is evident; de on-partijdigheid is immers nu juist de kern van de constitutionele rechterstak. ${ }^{23}$ Hoewel het het contradictoire en daarmee faire gehalte van het strafproces naar mijn mening ten goede zou komen wanneer de rol van de zitringsrechter nog 'rechterlijker' zou worden. Ik deel Leijtens overtuiging 'dat in het strafproces de ver-

${ }^{2}$ Ook in het butgerlijk recthe zijn de partijen veelal zeer ongeljk; ook her Wetbock wa burgerlike rechtsvordering kent ingrijpende "middelen tot bewaring wan zijn reche" (vgl. o.m. Derde Boek, vierde titel).

* Darbiy kan wel, met De Brauw, worden angetekend: "In het strafproces staat de verdediger net alleen tegenower en tegenpartij die formel ton matericel aen andere positio inneent, hij staat in zekcr opzich ook tegenover de rechter, when taak in het stratproces is namens de Statu schuldigen te straffen. Die taak omvat ook gebleken onsethuld vast te stellen; docl van ziju optreden is primair strafoplegging en in verreweg de meeste zakin windt die ook plats' (P.J. de Braw, Agemene beschouwingen over de positic vary de advocat in strafzaken, in: Advocast en praktijh. Alphen alan den Rijn (Samsom), losbl. Hoewel de praktijk De Brauw gelijk geeft lijk het mij zuiverder om de advocat niet zozeer tegenover de straffend", mar tegenover de onderzokende techtor te stellen. 
haalstructuur, en daarmee de poging om recht te doen, beter uit de doeken zou komen als een van de personen die straks over het feit moet oordelen - de voorzitter - niet zo actief betrokken was bij het geheel, dat elk verhal via zijn tussenkomst kleur en betekenis krijgt. ${ }^{29}$ Mar OM en verdachte kunnen in het perspectief wan het wetboek van 1926 , dat zoals Groenhuijsen overtuigend heeft uiteengezet ${ }^{30}$ het perspectief is van de mensen-en burgerrechten, in ieder geval trefzeker als strijdende partijen worden gekenschetst, ook al zijn zij "niet gelijk en hebben (zii) bijgevolg ook niet de beschikking over gelijke strijdmiddelen". "Wil van het partijschap van de verdachte echter iets terecht komen, dan is een bepaald minimum van deskundige bijstand vereist. Simons beschouwde de invoering van rechtsbijstand tijdens verhoren in het vooronderzock als éen van de belangrijkste nova die het wetboek van 1926 bracht. ${ }^{32}$ De rol van de raadsman krijgt extra betekenis wanneer men bedenkt dat in ons systeen de rol van de rechter niet bestat uit lijdelijke procesbewaking (zoals in het Angelsaksisch strafproces), maar dat zowel de rechter-commissaris als de zittingsrechter mede een actieve opsporingstaak hebben te vervullen. De raadsman zal dus in her belang van zijn cliënt, maar op een ander niveau bezien ook in het algemeen belang, als het ware een deel wan de procesbewakingstaak moeten ovememen.

\section{De verdediging heeft geen publiekrechtelijke functie}

De proceshouding van de verdachte is in de woorden van Melai 'aan geen andere regels gebonden dan aan die van een zekere orde in verband met de gedingvoering. ${ }^{33}$ Dat geldt zelfs voor de "grensoverschrijdende verdachte, ${ }^{34}$ die het stelsel waarop het gehele straf(proces) recht is geba-

J.C.M. Leijten, We need stories (afscheidsrede KU Nijmegen 3 mei 19gr). Zwolle (W.E.J. Tjeenk Willink), ngon, blz. 12. De Amsterdamse vice-president S. Slagker heet mecrmallen vergelijkbare suggesties gedan.

H.S. Groenhuijen, De rol van de mensen-en burgerrechten in de hereiening van het Wetboek van Strafwordering van 1926, in Dellikt on Delinkwervt 19 (1989), ble. 505-523, m.n. blz. 522 .

$\$$ Groenhuijsen, ta.p., blz, $\$ 23$.

Mrocnhuijsen, ta.p., bla 512 .

3. Melai, ta.p., blz. 168.

th Vgl. Cleiren, ca.p. en Pteter Herman Bakker Schut, Ties Praklken, Theo de Roos, 
seerd principieel, op politicke of morele gronden, verwerpt en het "spel nict wenst mee te spelen'. Het gebruik van aan de verdachte toegekende rechten en bevoegdheden dat door representanten van deze categorie word gemaakt kan niet 'op grond van veronderstelde legitimiteit worden beperkt tot de door de rechtsstalat beoogde strekking van die rechten en bevoegdheden. In deze opvatting kan men daarom gebruik van rechten en bevoegdheden door de verdachte nimmer $k$ walificeren als misbruik wan oneigenlijk gebruik', aldus Cleiren. ${ }^{35}$

Nimmer: dus ook niet wanneer het optreden van de verdachte de voortgang van het onderzock ter terechtzitting verstoort zonder dat nu direct gezegd kan worden dat hij de "stilte of de orde op de terechtzitting stoort', maar door vertragingstactieken en dergelijke? Volgens Cleiren kan wel sprake zijn van misbruik van procesbevoegdheden door de verdachte (de verdediging), doch slechts dan, wanneer het desbetreffende optreden "volstrekt niet meer past of apert in strijd is met de strekking van de bevoegdheid en zijn belang nier meer een rechtens te beschermen belang kan worden genoemd'. De rechter zou volgens haar in dergelijke gevallen het optreden van de verdediging negatief mogen sanctioneren (bijvoorbeeld door een verzoek tot anhouding te weigeren) zonder met het legaliteitsbeginsel van art. I $\mathrm{Sw}$ in strijd te komen, maar uitsluitend wanneer het gat om apert duidelijke gevallen van oneigenlijk gebruik of misbruik van bevoegdheid, m.a.w. bij kennelijk chicaneus handelen'. ${ }^{37}$ Een uiterst marginale toetsing dus, en zelfs dan 'blijft grote voorzichtigheid geboden'. ${ }^{38}$ Inderdaad zijn de rechten en bevoegdheden van de verdachte niet van publiekrechtelijke aard, zoals die van de officier van justitie en de rechter. De verdachte heeft geen boodschap aan beginselen van een goede procesorde; het staat hem vrij - in ieder geval binnen het zeer ruime kader zoals dat door Cleiren wordt geschetst - om zich willekeurig op te stellen omdat cen beginsel

$\rightarrow$

Politick protest in de rechtzal, in: Recht en kritick 1982, blz. $188-217$.

se Cleiren, t.a.p., bliz. 158 .

36 In dat geval kan nl. na een voorafgande warschuwing zjon verwijdering door de voorzitter worden bevolen, warna de zaak op tegenspraak buiten zijn annezigheid kan worden woortgezet.

${ }^{37}$ Cleiren, t.a. p., blz. 16r.

34 T.a.p., bilz. 162 . 
van redelijke afweging voor hem niet geldt; hij mag het vertrouwen dat hij bij het Openbaar Ministerie heeft opgewekt door te beloven geen verzoek tot aanhouding te doen indien het OM een bepaalde getuige zou oproepen en deze vervolgens niet zou verschijnen, schenden ondat een sanctie naar analogie van de niet-ontvankelijkverklaring wegens schending van het vertrouwensbeginsel hem niet kan worden opgelegd, (of zoiets verstandig is, is een andere kwestie).

Met Cleiren ben ik van mening, dat het bedenkelijk is om beperking van de bevoegdheden van de verdachte door de rechter te baseren op de strekking van die bevoegdheden in dier voege, dat hun uitoefening niet behoeft te worden toegestaan wanneer de verdachte daardoor 'niet in zijn verdediging is geschaad' (de 'Schutznorm'-redenering). In plaats van terug te grijpen op de fictieve 'wil van de wetgever' zou de beperkingsbevoegdheid rechtstreeks moeten worden gebaseerd op de taak van de rechter, gedurende het onderzoek ter terechtzitting enerzijds de strafprocesrechtelijke waarborgen van de verdachte te garanderen, anderzijds de juiste en doelgerichte voortgang van het proces te verzekeren. In deze gedachtengang heeft de verdachte in ieder geval het recht zijn rechten en bevoegdheden onbelemmerd wit te oefenen voorzover zijn acties 'met het doel van het strafproces niet onvoorwaardelijk in strijd komen'. ${ }^{39}$ Dat laatste zou het geval kunnen zijn bij kennelijk zinloze verzoeken, eindeloze betogen zonder pointe en dergelijke. Maar het zou zeker niet het geval zijn wanneer de verdachte bijvoorbeeld een requisitoir houdt tegen de heersende maatschappijvorm en de legitimiteit van het stelsel van strafrechtspraak.

Men zou het ook zo kunnen zeggen: of een verzock of andere proceshandeling in het belang van de verdediging is, maakt die verdediging zelf uit. 'De professionele solidariteit betekent dat de advocaat niets mag doen of nalaten wat in strijd is met de belangen van de verdachte; en dan bedoel ik bepaald niet de belangen van de verdachte zoals het openbaar ministerie en de rechter die zien". Pas als de

39. Aldus de memoric van toelichting bij het ontwerp voor het Wetbock van strafwordering van 1926 , opgenomen in A.L. Melai c.s., Het weboek van strafvordering (losbl.).

40 Aldus P. Mout, Korte notities over de radsman in strafzaken, in: Naar eer en geweten. (Liber Amicorum J. Remmelink), Amhem (Couda Quint), a.987, blz. 388. 
verdachte door zijn gedragingen zou verhinderen dat het doel van de procedure zou kunnen worden bereikt kan er sprake zijn van rechterlijk restrictief optreden, gezien de hem toegewezen taak. De rechter bewakt nict alleen de 'fysicke' orde, maar ook de 'geestelijke' orde, hij staat er garant voor dat het recht zijn loop heeft. Wanneer de wet hem witdrukkelijk de leiding der terechtzitting opdraagt (art. 274 eerste lid Sv) en hem bij ordeverstoring door de werdachte zelfs de bevoegdheid geeft de verdachte uit de rechtszaal te doen verwijderen (art. 303 Sv) kan hij ook sturend en beperkend optreden ten aanzien van de processuele gedragingen van de verdachte c.q. de verdediging.

\section{Wat betekent dit voor de raadsman?}

Ondat de verdachte geen publiekrechtelijke functionaris is, is de raadsman - wiens bevoegdheden ter terechtzitting in feitelijke instanties afgeleid zijn van die van de verdachte - dat evenmin.

Hij wordt wel aangeduid als "Unabhaengiges Organ der Strafrechtspflege ${ }^{31}$ dan wel 'officer of the court'. ${ }^{42}$ Het is niet toevallig, dat juist auteurs die cen ruime ervaring hebben als advocaat in strafzaken, zoals Mout, ${ }^{43}$ Sutorius ${ }^{44}$ en Prakken, ${ }^{45}$ hoe verschillend zij over vele belangrijke de strafrechtspleging betreffende zaken wellicht denken, over de positie van de raadsman volstrekt eenstemmig zijn. Toch zou ik niet van een op dit punt "heersende leer" willen spreken, om te beginnen. omdat ik aan die term een instinctieve hekel heb. Maar vooral, ondat het optreden van de advocaat in strafzaken ook recentelijk steeds weer voorwerp is van discussies, waaruit in heder geval naar voren komt dat er

4) Over dit begrip Janse de Jonge en Prakken, t. a.p. (noot 23).

2. Deze cern wordt gebruikt door L.C.M. Mejjers in NR.C-Handelsblad 20 mant 199 1, in cen korte reactic op mijn reactie (NRC-Handelsblad 19 mart 1991 ) op ecen interview met de pasbenoende Arnhemse Advocant-General W. Sorgdrager (12 mart 1991). Over dit debatje en de vormfoutendiscussic, zic de noot van A.C. "t Hart onder HR 22 februari 199\%, NJ 199 . 527 (bl2. 2247).

4. T.a.p. (noot 40)

* E.Ph.R. Sutorius, Rol en takopvatting van de radsman. Hoofdscuk I (suppl. 28 , september 1988) in: Vademecum strafzaken. Amhem (Gouda Qunt), losbl. m.n. bla. $45 \mathrm{~cm}$. 
nog steeds - of misschien moet ik zeggen: opnieuw, in deze tijd wan grimmige ontwikkelingen op het criminaliteitsfront-sprake is van nogal verschillende opvattingen over wat een advocat in strafzaken behoort te doen en na te laten. Het gaat dan met name om de vraag, of de raadsman bewust mag aansturen op zodanige complicaties, dat de kans op stranden van de vervolging ten gevolge van zogenaamde vormfouten, dan wel het overschrijden van de redelijke termijn in de zin van art. 6 eerste lid EVRM aanzienlijk wordt vergroot. Korter gezegd: mag de raadsman, in het op zichzelf legitieme streven de belangen van zijn cliënt te verdedigen, "zand in de machine gooien"? En ook een andere vraag wordt wel gesteld: mag de radsman zijn clënt doen profiteren van een vormfout, ook wanneer dat betekent dat een voorlopig gehechte verdachte in een zeer ernstige zaak op vrije voeten moet worden gesteld, mogelijkerwijs met het gevolg dat hij zich aan de verdere berechting zal ontrekken $?^{46}$ De emotionele lading warvan dergelijke vragen uitdrukking zijn zorgt ervoor, dat een zakelijke beschouwing al snel wordt bemoeilijkt. Slaagt men erin de kwestie wat afstandelijker te bezien, dan valt slechts te constateren dat noch het recht, noch de ethiek de advocaat verbieden de voor de cliënt subjectief gunstigste weg te volgen. Afgezien van de hierboven al vermelde inhoud van de advacateneed (art. 3 Advocatenwet) noet in dit verband wel worden gewezen op regel 2 Gedragsregels 1980 : 'De advocaat moet zich onthouden van elke mededeling waardoor de rechter of de tegenpartij wordt misleid'. Daarmee wordt een wat breder terrein bestreken dan de keiharde leugen: men kan ook misleiden door middel van een mededeling waarvan men redelijkerwijs moet aannemen, dat deze bij degeen voor wie de mededelling is bestemd een onjuist beeld van de werkelijkheid in het leven roepen. Voorts is er onder de advocaatauteurs - om die term maar even te gebruiken - contmuis opinio, dat de raadsman de justitiële inspamingen om de zaak tot een oplossing te brengen (de nerkwaardige term 'waarheidsvinding' wordt in dit verband vaak gebezigd), "voor zover geschied met inach tneming van de rechten van de verdachte" niet mag verhinderen. ${ }^{47}$ Maar binnen dit vrij

thie rubriek advocaturur, DD 2 (1991), blz. $198-200$, en de in noot 42 vermelde annotatie wan "t Hart.

47. Vgl. Mout, ta.p. blz. 387, ook verwijzend nar het klassick opstel wan D. Simons, De advocat on her strafproces, Tijdschrift voor Strafredut 1921, biz. 357 c.v. Zic 
ruine kader dient de advocaat, juist in het belang van de kwaliteit van de rechtspleging, een volledige vrijheid te genieten, ook wanneer dat leidt tot botsingen, wrijvingen en misverstanden met de vertegenwoordigers van de zittende en staande magistratuur. Waarbij de raadsman natuurlijk wel in het oog zal moeten houden dat cen effectieve verdediging niet gediend is met het uitvechten van principielle geschillen over de rug van de client. ${ }^{48}$ Het belang van deze laatste, zoals dit wordt gedefinieerd in het naar buiten toe gesloten front van de verdediging, blijft het belangrijkste richtsnoer. ${ }^{49}$

Ik ga op de taken van de raadsman, en de beperkingen waaraan de uitoefening daarvan is onderworpen, nu wat dieper in.

\section{Twijfel zaaien, verwarring stichten}

Simons leerde de strafrechtsadvocaat, dat zijn voomaamste functie in het strafproces bestond in het zaaien van twijfel. ${ }^{50}$ Zo dwingt hij het Openbaar Ministerie de zaak zo sterk mogelijk te presenteren, en de rechter om zorgvuldig na te gaan of de feitelijke en juridische basis voor een veroordeling aanwezig is. En daarmee levert hij een wezenlijke

\section{$\rightarrow$}

ook de preadviezen voor de Nederlandse Orde van Advocaten van $H$. van Butren en Th. W. van Veen, De positie van de advocaat in het moderne strafproces, Bijlage bij het Advocaten blad wan is a agusustus 1969 , blz. $329 \mathrm{~cm} 347-348$, en A.L. Melai c.s., Het Wetbock wan strafvordering, commentaar op de arte. 37-51, m.n. de nrs. $16 \mathrm{e} . \mathrm{v}$.

18 Vgl. J.L. de Wijkerslooth, Ethick en advocatuur. Nieuwenhoflezing RL Limburg d.d. 27 mei 1989. Deventer (Kluwer), 1980 : 'Wie niet oppast heeft geen cliënten meer, maar pionnen op een schaakbord'. Zic ook de noot wan G.P.M.F. Mols in Advocatenblad 1991 (nr. 12), blz, 496-499, onder Hof van Discipline 22 april 199 . nar. $14.96 \%$

4. Vgl. Mout, t.a.p., blz. 388: de ráadsman 'zal moeten beschikken over moed en tact om eventueel bij de rechter bestaande weerstanden tegen zijn optreden te overwinnen. Wat dit latete betreft: $\mathbb{K k}$ vermoed dat $\mathrm{er}$ nog heel wat rechters zijn die de liberale, dialetische takopvatting onjuist achten.' Hetgeen mede kan worden verklaard door thet verschijnsel, dat heel wat rechters-zoals heol wat advocaten - weinig affiniteit hebben met het 'ruige' strafrecht.

sal Vgl. diens in noot 48 genoemd opstel uit $192 \mathrm{r}$. In die tijd was zo'n standpunt (nog) minder vanzelfsprekend dan tegen woordig. Vgl, veel later de opvattingen van Van Busuren, t.a.p., noot 48 . 
bijdrage aan de kwaliteit van de strafrechtspleging. Een belangrijk aspect van dit twijfelzaaien is het stichten van veruarting. Dit vereist enige toelichting, ook al omdat ik hierboven betoogde dat de advocaat de vaststelling van feiten niet mag hinderen.

Maar wat zijn de feiten? Of, zoals de sceptische Pilatus - niet het voorbeeld van de meest karaktervolle rechter trouwens - aran Jezus vroeg: "Wat is waarheid?"' De volgende verwarrende vraag dient (onder andere) door de verdediging steeds - op de één of andere manier; dat is een kwestie van uitwerking en casuistiek - aan de orde te worden gesteld; is er voldoende wettig bewijs dat her feit, dat telaste is gelegd, door de verdachte is gepleegd?

Bijvoorbeeld: telastegelegd is het 'wegnemen van een jas met het oogmerk van wederrechtelijke bevoordeling' (art. 3 ro Sr). Is er door de verdachte weggenomen? Dat is uiteraard heel simpel, want het abc van het strafproces: het telastegelegde dient te worden bewezen; wanneer het Openbaar Ministerie niet in dat bewijs slaagt dient vrijspraak te volgen. Maar het wordt ingewikkelder, wanneer de verdachte erkent de jas in kwestie well in handen te hebben gehad, zoals door getuigen ook is gesignaleerd, maar deze niet te hebben 'weggenomen'. Laat staan dat an het 'oogmerk'-vereiste zou zijn voldaan. Zeker wanneer men bedenkt dat het bewijs van subjectieve bestanddelen in het geval van ontkenning slechts door uiterlijke omstandigheden kan worden geleverd (er is dan bijna altijd van 'circumstantial evidence" sprake) wordt duidelijk, dat zelfs vrij simpele feiten steeds meerduidig zijn, steeds in een ander perspectief kumnen worden geinterpreteerd. Het is aan de raadsman, die alternatieve perspectieven te presenteren. ${ }^{52}$ De daardoor

51 Johannes 18, 37: 'Jezus antwoordde: Gij zege, dat ik koning bon. Hicroe ben Ik geboren en hiertoe ben Ik in de wereld gekomen, opdat Itk woor de warheid zou getuigen; een ieder, die tit de waarheid is, hoort naar mijn stem. Pilatus zeide tor Hem: Wat is warheid?". Ook in dit proces trad geen adwocat op. Voot Jezus" oognerk zou deze bijstand, evenals in het geval van Socrates, slechts storend zijn gewcest. De radsman zou zijn werk trouwens letterlijk pro Deo bebben gedan.

\$2 Vgl de knappe beschouwingen van sutorius (t.a.p., noot 44 , blz. 6-8 c.v., over de "gereduceerde werkelijkheid" wan thet strafproces. Sutorius spreckt ook van de wertrechtering van het feicenmaterial gaande het proces. Zell gebruikte ik de termen stilerng en dubbele selectiviteit in dit verband. Wgl. Naar een contradictoir vooronderzoek? Mini-instructie op verzoek van de werdwchte, in: Dellkt en Delinkwent 2. (1991), blz. 599-611, m.n. blz. 601-602). 
teweeggebrachte verwarring kan bijdragen aan de twijel an de schuld wan de verdachte. Uiteraard is de raadsman beperkt door de algemene proceshouding van zijn cliènt, en door de eis van een minimum aan geloofwardigheid.

Onnodig te zeggen, dat bij ingewikkelder zaken een veelvoud van concurrerende interpretaties zal zijn aan te voeren. Bijvoorbeeld grote fradezaken, waaraan Chrisje en Kees Brants hun gemeenschappelike dissertatie wijdden: ${ }^{53}$ 'Bij grote fraudezaken warin het om reguliere ondernemingen en/of het leidinggevende personeel gaat, waar bovendien de rol van de overheid of structureel politiek-economische aspecten in het geding zijn' wordt "de kwalificatievraag veel vaker uitdrukkelijk aan de orde gesteld, de omvang, de duur en de complexiteit van $\mathrm{de}$ zaak zelf bieden de mogelijkheid om steeds nieuwe informatie aan te voeren waardoor het reduceren tot strafrechtelijk relevante feiten aanzienlijk wordt bemoeilijkt. In dit soort zaken kunnen raadsman en verdachte (...) buiten de, door het OM in zijn definitie opgeworpen, grenzen treden'. Voor de verdediging is het de kunst, roet in het eten te goolen: 'Zaken warin de definitie van criminaliteit ter discussie staat bieden daarvoor bij voorbaat meer mogelijkheden, omdat het daar gaat om de strafrechtelijke relevantie van de hele zaak. ${ }^{54}$

Ongemerkt zijn wij bij een andere categorie verwarringzaaierij uitgekomen. Hier galt het niet zozeer om de interpretatie, maar on de waadering van de feiten. Juridisch vertaald kan het gaan om uiteenlopende verweren: niet-ontvankelijkheidsverweren, beroepen op rechtvaardigingsgronden, schulduitsluitingsgronden, bewijsverweren (namelijk wanneer de delictsomschrijving daartoe aanleiding geeft, zoals wanneer de term 'wederrechtelijk' daarin is opgenomen) en de volkomen ten onredite wel geminachte strafmatverweren. ${ }^{55}$ Vast staat, om een actueel voorbeeld te nemen, dat een bedrijf zonder vergunning krachtens de Wet verontreiniging oppervlaktewateren gif-

5. G.H. Brants, K.L.K. Brants, De socinle constructic van frade. Amhem (Gouda Quine), Utreche (Whlem Pompe Instrutut 1991, ble. I 82.

sial Brants on Brants, toap. bla. 236.

5.5 Er word wel meemulend over "verzocken on clementic" gesproken. Het gaat echer niek om genadebrood, naar on de argumenten voor een juridisch deugdelijke, rohtvardige on 20 mogelijk effectieve sanctionering. Daar valt soms heel wat over te zeggen, on ook heel wat an to doen (denk bijvoorbeeld aan de dienstuerlewing, de rol van de reclassering en andere hulpverlerwing enz.). 
tige stioffen heeft geloosd. In principe state de stratbaarheid van dat feit buiten kijf, op grond van de genoemde wet en de Wet op de economische delicten (eventueel ook artikel 173 a of $173 \mathrm{~b} \mathrm{Sr}$ ). Maar wat, indien de voor de verstrekking van de bewuste verguningen verantwoordelijke overheden van de lozingen op de hoogte waren en deze hebben gedoogd? Dat gedogen kan een actieve en een passieve vorm aannemen. Bij de actieve vorm is wel sprake van een convenant, met zeer gedetailleerde voorwaarden, en naar de vorm nauwelijks van een vergunning te onderscheiden. ${ }^{56}$ Welke gevolgen kan dat hebben voor de vervolging? Het is hier niet de plats om dat onderwerp verder uit te spitten. Het gaat me in dit verband er slechts om te laten zien, dat creatieve advocaten een scala mogeijkheden ter beschikking staat om het perspectief van het Openbaar Ministerie zodanig onder te laten sneeuwen, dat hun cliënten, zo zij al niet geheel wrijuit gaan, toch niet als zondebokken voor een collectieve zonde worden behandeld.

Het is goed er in dit verband op te wijzen, dat een advocaat die ervoor zorgt dat zijn cliënt wordt ontslagen van alle rechtsvervolging, laat ons zeggen - om bij het gekozen voorbeeld te blijven - omdat hij een rechtvaardigingsgrond uit bestuurlijk (actief) gedogen heeft weten te destilleren, ten onrechte wel eens wordt gezien als een handige jongen die zijn pikzwarte klant als een onschuldig lammetje weet te presenteren en hem daarmee zijn verdiende straf doet ontlopen. Het vormt juist een onmisbare bijdrage aan de legitimiteit wan een politiek systeem, en aan de dynamiek van de samenleving, wanneer het gedrag van de verdachte wordt geplaatst in een context die veel kan verklaren, en misschien ook het één en ander kan rechtvaardigen of verontschuldigen. Soms ook door met de beschuldigende vinger naar de falende overheid of derden te wijzen. $\mathbb{Z}$ o kan het strafproces cen proces van ontdekking worden. Mout citeert in zijn meergenoemd artikel het adagium: 'Du choc des opinions jaillit la vérité ${ }^{3.7}$. Inderdaad is juist het contradictoire karakter van het proces bij uitstek een warborg tegen overmatige reductic en stilering van feiten en context. De 'liberale dialectiek' (Mour) die een

5. Vgl witworig en grondig over deze materic: M.G. Faure, De gevolgen van "administratieve afhankelijkheid", in: Zorgen van heden. Opstellen over het niliewstrafrechtin theorie en prakcijk. Anhthem (Gouda Quint) 1991, blz 9:-150 m.n. bla. $142 \mathrm{cov}$.

57 P. Mout, tap., ble. 387 . 
radsman moet toepassen, het 'pendelen' tussern rechtsnormen en het belangenperspectief van zijn cliènt, is daarmee cen zeer geschikte methode om de dictatuur van de eenduidigheid, van het "officiele" perspectief te bestrijden. Bestuurlijke en sociale problemen worden zo zichtbaar, en de tocpassing van het strafrecht draagt daardoor indirect, maar reej, bij aan sociale verandering.

\section{De raadsman in de tegenaanval}

Er zijn situaties waarin het geboden is, dat de raadsman geen blad voor de mond neemt, en in foro dan wel tegenover de publiciteitsmedia in de tegenaanval gaat. Dat kan door betrokkenen, bijvoorbeeld het slachtoffer van het misdrijf waarvan de cliënt wordt verdacht, als kwetsend worden ervaren. Hoever mag de radsman gaan?

Een advocaat treedt op voor een van gekwalificeerde mishandeling en wederrechtelijke vrijheidsbeneming verdachte, en in voorlopige hechtenis genomen man. Het slachtoffer is directrice van de school waarop zign 9-jarig dochtertje zat. De cliënt beweert tegenover zijn advocaat, dat het slachtofter zijn dochter ontuchtig had bejegend. Klachten zijnerzijds bij diverse autoriteiten hadden niets opgeleverd. Het slachtoffer heeft tijdens de ontvoeringsactie een verklaring getekend warin zij de ontuchtige handelingen tocgaf. Deze verklaring nu wordt door de raadsman door middel van een persbericht wereldkundig gemaakt, zonder dat hij de inhoud eerst checkt bij het slachtoffer, het schoolbestuur of de bevoegde autoriteiten. In de bewuste verklaring worden zeer pregnante details vermeld. Tegelijkertijd dient de radsman cen verzoek tot schorsing wan de voorlopige hechtenis in, waarin hij zich uitsluitend baseert op de onder dwang getekende verklaring van de directrice, en op een door de ouders weergegeven verklaring van thet meisje over de periode dat zij tussen 23 maanden en zes jaar oud was.

Duidelijk is, dat de intentie van de advocaat erin bestond zijn cliënt te helpen. Tijdens de behandeling van de tuchtzaak (de directrice had een

5\# 'Narrativiteit' en 'Stories' behoeden ons woor verstening: vgl. R. Foqué, A.C. 't Hart, Instrumenaliteir en rechesbescherming. Arnhem (Gouda Quint) 1990; J.C.M. Lejuten, ta.p. (noot 29 ). 
klacht ingediend bij de Raad van Discipline) beriep hij zich ter verdediging op de wrees van zijn cliënt dat 'de zaak' de doofpot zou ingaan. en op het belangr yan zijn cliënt om op wrije voeten te worden gesteld en te zijner tijd een langdurige gevangenisstraf opgelegd te krijgen. De vraag is of die intentie het schadelijk optreden tegen de directrice en de school rechtvaardigt. Gedragsregel 3 luidt: De advocat dient zich in woord en geschrift steeds op gepaste wijze en in geen geval onnodig grievend uit te laten. Maar wat is 'ongepast'?

De tuchtrechter gunt de advocaat een aanzienlijke spreek vrijheid. De uitlating mag niet nodeloos kwetsend zijn, zij moet in verband met de behandelde zaak van belang zijn (relevantiekriterium) en de advocaat moet kunnen menen dat zij niet in strijd met de waarheid is. "Ongelukkige' bewoordingen zijn niet voldoende voor bestraffing. ${ }^{5 \%} \mathrm{Niet}$ alle voor betrokkenen schadelijke uitlatingen zijn ongeoorloofd: aan de advocaat komt in zijn functie ter zake een grote vrijheid toe. Daarom zal - aldus de formulering van de hoogste tuchtrechter ${ }^{\text {(ii }}$ - 'de grens voor een advocaat enigszins ruimer liggen dan voor anderen het geval is.' Anderzijds moet een advocaat zich wellicht ook meer dan anderen bewust zijn 'van het gezag dat van zijn uitlatingen kan uitgaan en de beperkingen die hij zichzelf daarom moet opleggen'. Naar aanleiding van een geruchtmakende zaak warin een advocaat zich in cassatie keerde tegen een door het gerechtshof bij wijze van bijzondere voorwaarde opgelegd contactverbod met betrekking tot een in een incestueuze relatie verwekt (klein)kind, werden door enkele hulpverlenende stichtingen en door collega's tuchtrechtelijke klachten ingediend, die door de tuchtrechter ongegrond werden verklaard, onder meer met de volgende overweging: "Inhaerent an de verdediging in strafzaken en in het bijzonder in het geval van de verdediging van verdachten van zedendelicten is dat het optreden van de advocaat van de verdachte door het slachtoffer wak als grievend en kwetsend wordt ervaren, doch dat ontneemt de advocaat deswege niet de vrijheid (...) stelling te nemen tegen gevestigde opvattingen en/of heersende normen'.

5 Hof van Discipline 13 jull 1987 (nr. 950), Mols/Mallherbe tap. (noot 9), blz. 52 .

Hof van Discipline is juni 1900, Adwocatenblad 1990, blz. $551-553$ m.nt. H.J. Pot.

fi $\mathrm{DD}$ (rubrick advocatuur) 20 (1990), bliz. 260 . 
Ter vergelijking vermeld ik de stand van zaken op dit punt naar (West)duts recht: volgens de tuchtrechter en het constitutioneel hof te Karlsruhe zijn uitlatingen van advocaten slechts in strijd met het tuchtrecht wanneer zij "nach Inhalt oder Form als strafbare Beleidigungen zu beurteilen sind, ohne durch die Wahmehmung berechtigter Interessen gedeckt zu werden". Daamaast kan van schending van de beroepsplicht slechts worden gesproken in een beperkt aantal gevallen, bijwoorbeeld wanneer 'ein Anwalt unprofessionell handelt, indem er entweder bewusst Unwahrheiten verbreitet oder der Kampf ums Recht durch neben der Sache liegende Herabsetzungen belastet, zu denen andere Beteiligte oder der Verfahrensverlauf keinen Anlass gegeben haben'. ${ }^{63}$

\section{Zand in de machine?}

Zoals wij zagen mag de advocaat de waarheidswinding door de justitiele autoriteiten niet tegenwerken, en hij mag de rechter en het Openbaar Ministerie niet voorjokken. Maar een actief verdediger zal al snel de justitie - althans in de perceptie van de justitiele organen - hinderlijk voor de voeten lopen. Hoe moet nu het optreden worden beoordeeld van de radsman die, bewust gebruik makend van organisatorische feilen in het justitieel systeem, met gebruikmaking overigens van volstrekt oirbare (rechts)middelen, zijn voorlopig gedetineerde cliënt op vrije voeten weet te krijgen in een spectaculaire, emotioneel beladen en sterk in de belangstelling stande zaak? Om te beginnen moet worden opgemerkt, dat het natuurlijk niets mag uitmaken of de zaak sterk in de publiciteit is of niet. Mar het is genoegzam bekend, dat juist onder die omstandigheden (waar het bijvoorbeeld gat om verdenking van levensdelicten in zware zedendelicten) de vraag, of de advocaat in het belang van zijn cliẻnt 'zand in de machine' mag gooien, met klem wordt gesteld. Naar mijn stellige overtuiging is dit een schijnprobleen. Wie

42 Bundesverfassungsgericlat, 4 juli 1987 , gepublicerd in: Bundesrechtsanwaltskammer-Mitteilunger 19088 , ble. 54 e.v., m.n. blz. 57

"Men spreck in dir verband van het 'Sachlichkeirgabot". Overigens is de Dutse stij] van procederen minder harmonicus dan wij hier te lande gewend zijn. Wrakingen (Befangenthoitsantrage) zijn betrekkelik normale strijd nuiddelen, zeker niet alleen in politicko processen. 
witgaat van het beginsel dat schuld niet wordt yoorondersteld maar eerst moet worden aangetoond, en dat de verdachte - wettelijke nitzonderingen daargelaten, voorzover toelatbaar op grond van constitutioned en international recht ${ }^{64}$ - niet aan zijn 'Ueberfuehrung' behoeft mee te werken, en bovendien - zowel in het belang van verdachte burgers als met het oog op de legitimiteit van de strafrechtspleging - rechtsmiddelen ter beschikking krijgt, kan het de verdachte niet $k$ walijk nemen dat hij de wettelijke mogelijkheden ten volle uitbuit, en dat betekent tegelijkertijd dat hij de raadsman, die gezien zijn wettelijke tak en de vertrouwensrelatie met zijn cliënt deze laatste op de bestaande mogelijkheden moet attenderen, evenmin iets heeft kwalijk te nemen.

\section{De advocaat als heler}

Door toedoen van wetsontwerp 2 i $\$ 65$, ter aanvulling van het Werboek wan strafrecht en dat van strafvordering met voorzieningen ten behoeve van de bestrijding van heling, werd op het niveau van de wetgever weer eens de aandacht gevestigd op het juridisch en ethisch schemergebied, waarin de strafrechtelijke advocatuur zo vaak opereert. Het voorstel wil de bestaande regeling van opzet- en schuldheling (artt. 416, 4.17 en 417 bus Sr) zodanig wijzigen, dat wordt gebroken met het systeem wan enumeratieve opsomming van helingshandelingen. Voortaan zal elke uitoefening van zeggenschap (verwerven, voorhanden hebben, overdragen) over een door misdrijf verkregen goed, ongeacht de titel wan herkomst, binnen het bereik van de strafwet komen. De raadsman, die zich laat betalen door een cliënt die van heling wordt verdacht loopt naar geldend recht al de kans in de sfeer van schuldheling te belanden. De discussie binnen en buiten het parlement betrof de vragen, of dit risico ten gevolge van de in te voeren wijzigingen werd vergroot, en zo $\mathrm{ja}_{\text {s }}$ of er niet een beroepsexceptie ten behoeve van de bona fide raadsman moest worden opgenomen. Deze zou kunnen luiden: 'Niet strafbatar is de advocaat die wegens verleende rechtshulp een honorering ontvangt zoals een behoorlijk advocaat betaamt'. Deze tekst werd in het advies wan de Nederlandse Orde van Advocaten aan de Tweede Kamer

क Over dergelijke uitzonderingen zie o.m. G.P.M.F. Mols (red.), Justived onderzoek an en in het licham. Deventer (Kluwer), 1900. 
gesuggetcerd, en werd overgenomen door Groen Links-Tweede Kamerlid Ina Brouwer in een amendement, dat na ontrading door de minister van justitie werd verworpen. ${ }^{65}$

De redenering van de minister luidde als volgt: ook naar geldend recht is het zo, dat een advocaat die wordt betaald met geld, afkomstig uit de opbrengst yan een door misdrijf verkregen voorwerp, en dit weet of behoort te weten, strafbaar is. De voorgestelde verruiming van de delictsomschrijving doet daar niet wezenlijk aan toe. De raadsman zal nu en in de toekomst ook in strafrechtelijke zin op zijn tellen moeten passen. Maar de minister benadrukt, dat ten aanzien van de vervolging van advocaten wegens heling grote terughoudendheid is geboden, zoals is verwoord in een brief van de vergadering van de Procureurs-Generaal bij de gerechtshoven aan de Orde van Advocaten van 26 oktober 1989.66 In deze reactic op een roep om duidelijkheid van de kant van de advocatuur is met name de volgende passage van belang: 'In de strafprocedure staan raadsman (en verdachte) en officier van justitie tot op zekere hoogte tegenover elkaar. Deze tegenstelling van belangen en posities brengt (...) met zich mee, dat het openbaar ministerie dat een advocaat vervolgt ter zake van de wijze van honorering van de door dezen gevoerde verdediging, al gauw de verdenking op zich zal laden van intimidatie en repressie en verlies van afstandelijkheid. De antagonistische verhouding tussen openbaar ministerie en raadsman verzet zich dan ook tegen een dergelijke vervolging, buiten de gevallen van duidelijke, criminele betrokkenheid van de advocaat bij zijn cliënt. ${ }^{67}$ Dit uitgangspunt, zoveel blijkt wel wit de debatten over het wetswoorstel in de Tweede Kamer en de standpuntbepaling van minister Hirsch Ballin, geldt ook voor de toekomst, onder het nieuwe recht. ${ }^{68}$ De Orde

"Hand. Tweede Kamer 12 mant $199 \mathrm{r}, \mathrm{b} / \mathrm{z} .60-3397$ e v (het debaty; Tweede Kamer 1990-1991, $21565, \mathrm{nr} .10$ (amendement-Brouwer)

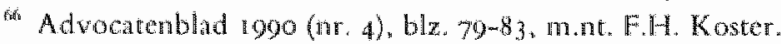

6) T.a.p., ble. 82.

Vgl over deze materie N, Jörg, De adwocat als heler, Advocatenblad 1985 (nt, 13), bl2, 295-298, die de Nederlandse stuate spiegelt an de RICO-wetgeving in de USA. Volgens de federalle Money Laundering Act blijwen "bona fide fees an atromey accepts for representing a clicnt in a criminal investigation or any procecding arising therefrom" buiten schot. Zie ook Delikt en Delinkwent (rubriek

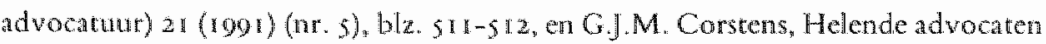
vervolgen is nice allijd gewenst, in: NRC-Handelsblad 20 oktober ro87. 
is niet tevreden met deze "rechtszekerheid van tweede garnituur", en heeft de Eerste Kamer-dat het recht van amendement ontbeert - verzocht het gehele wetsontwerp te verwerpen.

Afgezien van het probleem van de advocaat, die zijn rechtsbijstand aan de van heling verdachte in de huidige situatie met een letwat onrustig gevoel moet verlenen, zijn er nog complicaties met betrekking tot het recht op rechtsbijstand. Preventief gedetineerden krijgen ambtshalve een raadsman toegevoegd (art. 50 Sv), dus in die categorie valt geen 'gat'. Anders ligt het bij degenen die wel verdacht zijn, maar niet in voorlopige hechtenis zijn genomen. Mogelijkerwijs hebben zij wel in de fase van de in verzekeringstelling (art. 54 e.v. Sv) bijstand ontvangen van een piketadvocaat (art. $40 \mathrm{~Sv}$ ), maar wanneer geen inbewaringstelling is gevolgd, neemt deze door de overheid gefinancierde rechtsbijstand een einde, wanneer zij niet wordt gecontinueerd door middel van een verzoek aan het Bureau voor rechtshulp om toevoeging van een raadsman (art. 76 Advocatenwet). Degene die echter goed in de slappe was zit, komt niet voor toevoeging in aanmerking (nog daargelaten de mogelijkheid dat hij een betaalde raadsman zou prefereren) omdat hij genoeg middelen heeft orn zelf een advocaat te betalen. Maar wanneer de door hem angezochte advocaten zouden weigeren hem bij te staan omdat zij niet willen riskeren te worden betaald uit illegaal vermogen, zou hij uiteindelijk van rechtsbijstand verstoken moeten blijven. ${ }^{69} \mathrm{Het}$ Tweede Kamerlid Van der Burg suggereerde in deze gevallen de mogelijkheid van een 'voorwardelijke toevoeging' - een cloor de praktijk ontwikkelde, maar voorallsnog een hechte wettelijke basis missende figuur--, maar dat lijkt nogal werkelijkheidsvreemd. Het cruciale punt is, dat wil er iets van een effectieve rechtsbijstand terechtkomen, een vertrouwensrelatie onontbeerlijk is (zie ook de brief wan de Procureurs-Generaal), en die verdragt zich nu eenmaal slecht met een indringend onderzoek door de advocaat naar de herkomst van het hem ter beschikking gestelde honorarium. Met andere woorden: buiten de gevallen van criminele betrokkenheid of positieve wetenschap van de criminele herkomst zal de door de wet vereiste schuldintensiteit niet gegeven zijn, ondat in redelijkheid van de advocaat geen actief onderzoek terzake mag worden verwacht. En wanneer er in principe strafbaarheid zou kunnen zijn, is strafvervolging terzake in de regel niet 
opportuun. Duidelijk is wel, dat acceptatie van een zeer riant honorarium - hoewell op zichzelf geenszins strafbaar of zelfs maar tuchtrechtelijk dubicus - en indicatie zal kunnen zijn voor criminele betrokkenheid. De slotsom is, dat de spanning ten volle blijft bestaan. Bij aanvaarding van de door de Orde voorgestelde strafuitsluitingsgrond zou het probleem door de wetgever tot op zekere hoogte zijn weggedefinicerd. Mar niet helemaal, want, nietwar: wat is een vergoeding zoals 'een behoorlijk advocaat betaamt'? De caoutchouc-omschrijving van artikel 46 Advocatenwet laat nogal wat ruimte voor verschillende interpretaties. ${ }^{70}$

\section{Beïnloeding getuigen}

De advocaat moet zich onthouden van belemmering van de justitiële naspeuringen, en het spreekt wel vanzelf dat het 'bewerken' van getuigen opdat zij een voor de cliënt gunstige verklaring zullen afleggen zo al niet strafbaar, clan toch in ieder geval wit den boze is. Gedragsregel 25, tweede lid maant de advocaat - in enigszins antieke bewoordingen - de advocaat in strafzaken zich er (behalve in bijzondere gevallen) van te onthouden met getuigen die door het Openbaar Ministerie zijn 'aangezegd' vooraf te horen. De hoogste tuchtrechter heeft echter in diverse uitspraken de raadsman een ruime marge gegund om tijdens het vooronderzoek (piketfase, gerechtelijk vooronderzoek) op last van het OM door de politie gehoorde of door de R-C nog te horen getuigen te benaderen in het belang van een effectieve verdediging. Volgens het Hof van Discipline geldt het verbod uitsluitend met betrekking tot getuigen die door het $\mathrm{OM}$ ter openbare terechtzitting zijn gedagvaard of opgeroepen (en dan niet op verzoek van de verdediging).

In cen uitsprakk wan 1975 noemde het Hof van Discipline de regel 'verouderd, maar niet achterhaald'; verouderd, omdat hij stamt uit een periode dat de raadsman pas bij de vordering van een gerechtelijk vooronderzock of na voltooing van het opsporingsonderzoek in thet

7) Zoals de legistacieve debatten rond thema's als abortus on euthanasie leren, is de wetgewer niet scheurig met het opnemen van professionele exceptics in het Werbock van strafrecht. 
spel kwam, maar niet achterhaald, omdat de raadsman voorzichtig. moet optreden, wil hij zich niet an 'undue influence' schuldig maken."

Dat een advocaat ook uit pure naiviteit het onderzoek kan wersjteren blijkt uit een recente uitspraak van het Hof. $^{72}$ Een betrekkelijk onervaren advocaat optredend woor een bevriende confrère tegen wie, op verdenking van onder andere illegalle wapenhandel, een vordering tot bewaring en tot opening van een gerechtelijk vooronderzoek was ingediend, had telefonisch contact opgenomen met een zich in het buitenland bevindende, in de vordering gro imet name genoemde medeverdachte. Hij had de R-C verzocht, deze medeverdachte als getuige te horen. Het contact kwam naar voren, toen de argeloze raadsman tijdens de behandeling van de vordering tot gevangenhouding daarvan gewag maakte, en erbij vertelde dat de medeverdachte hem (weinig verrassend) had meegedeeld niet naar Nederland te zullen komen. Het Hof oordeelde dat in dit geval de advocaat zich niet had gedragen zoals een behoorlijk advocat betaamt, omdat zijn telefoontje naar redelijkerwijs viel te verwachten nadeel zou berokkenen aan de rechtmatige opsporing van de feiten — in het algemeen de rechtmatige warheidsvinding - door de justitiële autoriteiten. Het aftasten van (potentièle) getuigen - zowel á charge als á décharge; dir zijn overigens geen wettelijke termen - is een onmisbaar attribuut in het arsenaal van de raadsman, en dat daarvan enige beïnloeding uitgaat is onvermijdelijk. In abstracto is niet aan te geven wanneer deze invloed tuchtrechtelijk bedenkelijk wordt. Ook hier moet de advocaat in strafzaken dus op eieren lopen.

\section{Slot}

De strafrechtelijke rechtsbijstand is een uitdagend, omvangrijk on gecompliceerd wetenschappelijk probleemveld. Het Willem Pompe-instituut voor strafrechtswetenschappen van de Rijksuniversiteit Utrecht heeft aan de exploratie van dit terrein vanuit een kritisch-emancipato-

73 Mols/Malherbe, ta.p. bly. 128 .

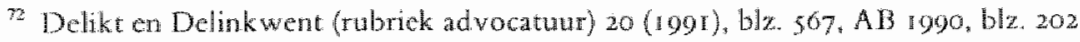
Hof van Discipline 8 december 1989 . 
rech perspectefeen krachtige impuls gegeven. In de vakgroep waar nu ben angesteld is met studies op deelterreinen en dissertaties-inwotdingen encrgicke voortzeting gaande. Het antal thema's dat zich leent voor nadere bestudering is schier eindeloos; de problematick van het verschoningsrech in combinatic met inbeslagneming bij geheimhouders, de anomieme getuige, het onmiddelljkheidsbeginsel (war collega Mols over oreerde in 1989$),{ }^{73}$ het contradictoire element in het vooronderzoek, het belang van de advocatum bij een redelike beloming, de toepassingspraktijk van het strafmoduubesluit, de ethische aspecten, beperkingenain de vrijheid van radsmankeuze, en last but not least de gevolgen van de internationalisering voor de advocatuur: het is maar een greep. In een tijdperk warrin rechtsbescheming en rechspleging als restposten worden behandeld - alle fraai opgetuigde retoriek die het tegendeel beweert ten spijt - staat de taak wan de raadsman in strafzaken onder grote druk: druk van de natuunlijke tegenstrevers, OM en politie, van de owerbelaste rechter, mat ook van de clienten. In deze situatic kan de raadsman aleen zijn plan trekken wameer zijn onafhankelijkheid is gegarandeerd. Verambteljking van de advocatuur moet daarom worden afgewezen, zoals vroeger ook plannen woor een ambteljke rechtsbijstand in strafzaken het niet hebben gehald. ${ }^{74}$

De witoefening van het beroep vereist een grote geestelijke lenigheid, en een behoorlijk juridisch problemoplossend vermogen. Het is vooral wan de advocatuur in het algemeen voorbehouden, de grenzen van het recht te verleggen en-war de wetgever defnitief naar een vrij bescheiden plaats in de rechtsvorming lijkt te zijn verwezen - creatief in te springen op de articulering van matschappelijke behoeften. In het strafrecht liggen echter de accenten iets anders. Daar is de wet van

G.P.F.M. Mols, Stande de zitung. Een beschouwing over het onmiddellikheidsbeginsel. Arnhem (Gouda Quind), 1989 .

74 "In leder geval is met het oog op het gevar van conflicten bij overtreding of afwijking van die regelen (ol. die in het belang van de werdachte zinn vastgesteld, de R.) en volledige onafhankelijkheid on aclfsandigheid geboden. War de verdediging door ambtenaren met vaste salarièring wordt gevoend, zal men dan ook ecrst verslapping zien opereden un het er voor waken, dat de rechten wan de verdachte mee in het gedrang komen, en darop zal dan licht volgen een verslapping van de verdediging zelf (...). Aldus in mei 1950 C.H. Beeklumis in zijn preadvies voor de jaarvergadering van de Nederlandse Orde van Advocaten, De posilie van de advocat in strafzaken. Advocatenblad 1950, blz. 195 . 
oudsher, en op goede gronden, belangrijker. De adwocatuur zal zich niet moeten toeleggen op het verleggen, maar op thet terugleggen van de grenzen, die tengevolge van een even creatief als repressief apparaat (denk aan het proactief optreden van de recherche, en de toenemende internationale justitiele samenwerking) voortdurend dreigen te verschuiven. Maar voor deze activiteit is minstens evenveel juridische inventiviteit vereist. Het is een goede zaak, dat de Stichting Strafrechtspraktijk nieuw leven is ingeblazen om op afzienbare termijn een respectabel aantal strafrechtsspecialisten voor de adwocatuur af te leveren. Ik vraag me overigens wel af, of de verplichte postacadenische beroepsopleiding die beginmende advocaten moeten wolgen de vereiste creativiteit voldoende bevordert. Het lijkt erop, dat de stagiaires "meer van hetzelfde' krijgen voorgeschoteld, in plaats van een minder op weetjes en feicjes gerichte, wat mij betreft "Maastrichtse" probleemgestuurde aanpak.

Ik ben aan het einde van mijn oratie. Ik dank het bestuur van deze universiteit voor zijn bijdrage aan mijn benoeming, en vertrouw op cen goede - in deze tijden broodnodige — samenwerking.

Aan mijn collega's van de faculteit zou ik willen zeggen:

onze faculteit bestaat nu Io jaar en vertoont hier en daar bedenkelijke trekjes van rijpheid. Dat heeft natuurlijk ook zijn voordelen. Maar ik reken erop dat wij de jeugdige trekjes van openheid en coöperativiteit kunnen handhaven, en zal mij daarvoor inspannen.

Mijn leermeester in het strafrecht aan de VU was G.E. Mulder, aan wie ik dierbare herinneringen heb-zoals een openbaar debatje over marxisme en recht warin hij de "heuristische warde" van het marxisme prees, mathet determinisme ervan veroordeelde.

Van de Pompianen noem ik Ties Prakken en mijn promoter Bert Swart als inspiratoren. Ties is als notoir lastig advocaat de "horzel op het paard" die ook Socrates wilde zijn voor de A theners, en daarbij is zij-gestaag producerend - niet in staat een oninteressant stuk te schrijven. Van Bert Swart waardeer ik de combinatie van juridische analyse en syn these, met een uiterst conscièntieuze en effectieve werkstijl. Nog belangrijker is, dat hij kennelijk wordt gedreven door de behoefte om de 
verschoppelingen van alle tijden, vreendelingen en strafklanten, tot hun recht te laten komen.

Met de redacteuren van Recht en kritiek (waaronder collega Gerrit van Maranen) voel ik mij in een Gideonsbende verbonden, al trad ik al zes jaar geleden uit de redactie. Tijdens de bijeenkomsten met Fred Melai en zijn redactie van de "losbladige strafvordering' steek ik veel op over de strafrechtspleging en haar protagonisten.

Mijn matjes van Van Asperen de Roos \& Pen ben ik dankbaar, dat ik niet helemaal afscheid behoefde te nemen van de advocatuur.

Na een jaar Maastricht woel ik me goed op mijn stek, en ik had niet anders verwacht. Het jonge-hondenimago van collega Gerard Mols draagt wezenlijk bij aan de profilering van vakgroep en faculteit, en ik laat me zijn tomeloze tempo graag aanleunen.

Onder de leden wan de vakgroep strafrecht en criminologie heerst een opgewekte stemming en een warme collegialiteit. Je zou niet zeggen dat hier een fors aantal dissertaties in voorbereiding is. Als iedereen straks is gepromoveerd kan het helemaal niet meer stuk.

De allerbelangrijksten zijn Marjet, Jeroen en Wouter. Tegelijk een proefschrift afmaken en een oratie schrijven, dàt is pas spannend. Jeroen en Wouter kunnen ervan meepraten. In één adem noem ik mijn geliefde moeder en broers, die mijn verrichtingen soms met geestdrift en steeds met sympathie volgden.

En dan ten slotte een boodschap aan de studenten: De visitatiecommissie makkte zich zorgen of U na Uw Mastrichtse opleiding voldoende oog zou hebben voor het systeem wan het recht en de diverse rechtsgebieden. Troost U: het systeem is er yoor de probleemoplossing, en niet andersom! Ik heb gemerkt, dat het bevorderen van $U w$ vaardigheid om problemen te lijf te gaan ook voor mij zeer leerzam is.

Ik heb gezegd. 